\title{
Variations in fluid activity across the Etive thermal aureole, Scotland: evidence from cordierite volatile contents
}

\author{
- $\quad$ M. J. Rigby \\ - G. T. R. Droop and \\ - G. D. Bromley ${ }^{2, \dagger}$ \\ 1 Department of Earth, Atmospheric and Environmental Science, University of \\ Manchester, Oxford Road, Manchester M13 9PL, UK () \\ 2 Bayrisches Geoinstitut, Universität Bayreuth, D-95440, Bayreuth, Germany \\ * Present address: Department of Geology, University of Pretoria, 0002 Pretoria, \\ South Africa. \\ ${ }^{\dagger}$ Present address: Department of Earth Science, University of Cambridge, \\ Downing Street, Cambridge CB2 3EQ, UK.
}

[Figures and tables at the bottom of the document]

\begin{abstract}
The $\mathrm{H}_{2} \mathrm{O}$ and $\mathrm{CO}_{2}$ content of cordierite was analysed in 34 samples from successive contact metamorphic zones of the Etive thermal aureole, Scotland, using Fouriertransform infrared spectroscopy (FTIR). The measured volatile contents were used to calculate peak metamorphic $\mathrm{H}_{2} \mathrm{O}$ and $\mathrm{CO}_{2}$ activities. Total volatile contents are compared with recently modelled cordierite volatile saturation surfaces in order to assess the extent of fluid-present $v$. fluid-absent conditions across the thermal aureole. In the middle aureole, prior to the onset of partial melting, calculated $a \mathrm{H}_{2} \mathrm{O}$ values are high, close to unity, and measured volatile contents intersect modelled $\mathrm{H}_{2} \mathrm{O}-\mathrm{CO}_{2}$ saturation curves at the temperature of interest, suggesting that fluid-present conditions prevailed. Total volatile contents and $a \mathrm{H}_{2} \mathrm{O}$ steadily decrease beyond the onset of partial melting, consistent with the notion of $a \mathrm{H}_{2} \mathrm{O}$ being buffered to lower values as melting progresses
\end{abstract}


once free hydrous fluid is exhausted. All sillimanite zone samples record total volatile contents that are significantly lower than modelled $\mathrm{H}_{2} \mathrm{O}-\mathrm{CO}_{2}$ saturation surfaces, implying that fluid-absent conditions prevailed. The lowest recorded $a \mathrm{H}_{2} \mathrm{O}$ values lie entirely within part of the section where fluid-absent melting reactions are thought to have dominated. Samples within $30 \mathrm{~m}$ of the igneous contact appear to be re-saturated, possibly via a magmatically derived fluid. In fluid-absent parts of the aureole, cordierite $\mathrm{H}_{2} \mathrm{O}$ contents yield melt- $\mathrm{H}_{2} \mathrm{O}$ contents that are compatible with independently determined melt $-\mathrm{H}_{2} \mathrm{O}$ contents. The internally consistent cordierite volatile data and melt $-\mathrm{H}_{2} \mathrm{O}$ data support the conclusion that the independent $P-T$ estimates applied to the Etive rocks were valid and that measured cordierite volatile contents are representative of peak metamorphic values. The Etive thermal aureole provides the most compelling evidence, suggesting that the cordierite fluid monitor can be used to accurately assess the fluid conditions during metamorphism and partial melting in a thermal aureole.

\section{Introduction}

The presence or absence of $\mathrm{H}_{2} \mathrm{O}$ - and $\mathrm{CO}_{2}$-rich fluids during crustal processes exerts a profound effect upon the evolution of rocks and mineral assemblages. Metamorphism and anatexis are two processes strongly dependent on the roles of $\mathrm{H}_{2} \mathrm{O}$ and $\mathrm{CO}_{2}$, as many of the reactions either involved release of volatiles through prograde devolatilization or consume them via retrograde and 'wet' melting reactions. The physicochemical environment in which many of these reactions proceed is not only dependent on the $P-T$ conditions of equilibration but also on the magnitude of the activities of the volatile species. Variations in $a \mathrm{H}_{2} \mathrm{O}$ and/or $a \mathrm{CO}_{2}$ have a dramatic effect on the stability of minerals, the identities of melting reactions and the positions and topology of reactions in $P-T$ space (e.g. Thompson, 1982; Powell, 1983; Waters, 1988; Pattison, 1991; Johnson et al., 2001). Traditionally $a \mathrm{CO}_{2}$ and $a \mathrm{H}_{2} \mathrm{O}$ in rocks have been estimated by applying thermodynamic methods to mineral-fluid equilibria (e.g. Holland, 1979; Droop et al., 2003). The problem with the traditional method, when attempting to assess the presence or absence of a fluid, is that it is difficult to estimate both $a \mathrm{H}_{2} \mathrm{O}$ and $a \mathrm{CO}_{2}$ simultaneously in a single rock sample. This is because few rocks contain assemblages that permit both pure dehydration equilibria and pure decarbonation equilibria to be written among end- 
members of the minerals present. Mixed volatile equilibria (e.g. Kerrick, 1974) can be written for many marbles and calcsilicate rocks, but are unsatisfactory in this respect as they can only provide upper limits on the $a \mathrm{H}_{2} \mathrm{O}$ and $a \mathrm{CO}_{2}$ corresponding to fluidsaturated conditions. The mineral cordierite, however, provides a potential solution to the problem.

Cordierite, $(\mathrm{Mg}, \mathrm{Fe})_{2} \mathrm{Al}_{4} \mathrm{Si}_{5} \mathrm{O}_{18} \cdot n \mathrm{H}_{2} \mathrm{O} \cdot m \mathrm{CO}$, contains a large channel site at the centre of its six-membered ring structure which can accommodate molecular $\mathrm{H}_{2} \mathrm{O}$ and $\mathrm{CO}_{2}$ (e.g. Wood \& Nassau, 1967; Goldman et al., 1977; Aines \& Rossman, 1984). Provided that the channel constituents are faithfully retained during equilibration and subsequent $P-T-t$ evolution, cordierite is a mineral with potential as a monitor of $\mathrm{H}_{2} \mathrm{O}$ and $\mathrm{CO}_{2}$ contents during metamorphism and anatexis (e.g. Newton \& Wood, 1979; Kurepin, 1985; Vry et al., 1990). In concert with independently determined $P-T$ estimates and thermodynamic data on cordierite volatile melt equilibria, measured cordierite volatile contents can be used to calculate $\mathrm{H}_{2} \mathrm{O}$ and $\mathrm{CO}_{2}$ activities. Furthermore, provided that cordierite $\mathrm{H}_{2} \mathrm{O}-\mathrm{CO}_{2}$ saturation surfaces are known for selected $P-T$ conditions, cordierite volatile contents can be used to ascertain the extent of fluid presence $v$. fluid absence (Harley \& Carrington, 2001; Thompson et al., 2001; Harley et al., 2002). In fluid-present environments the total volatile content of cordierite is variable but intrinsically dependent on pressure, temperature and $\mathrm{XCO}_{2}$ in the coexisting fluid (Mirwald \& Schreyer, 1977; Johannes \& Schreyer, 1981; Kurepin, 1985; Carey, 1995; Harley \& Carrington, 2001; Thompson et al., 2001; Harley et al., 2002). In fluid-absent, melt-present environments the cordierite volatile content depends on the partitioning of the volatile species between cordierite and the coexisting melt phase (Harley, 1994; Stevens et al., 1995; Carrington \& Harley, 1996; Harley \& Carrington, 2001; Thompson et al., 2001; Harley et al., 2002). In this paper, recent experimentally derived thermodynamic data on the incorporation of $\mathrm{H}_{2} \mathrm{O}$ and $\mathrm{CO}_{2}$ into cordierite (Harley \& Carrington, 2001; Thompson et al., 2001) are used to calculate the activities of fluid components, and using modelled $\mathrm{H}_{2} \mathrm{O}-\mathrm{CO}_{2}$ saturation surfaces (Harley et al., 2002) map out the extent of fluid-present $v$. fluid-absent conditions across the Etive thermal aureole. In fluid-absent, melt-present parts of the terrane the cordierite $-\mathrm{H}_{2} \mathrm{O}$ contents are used to estimate the $\mathrm{H}_{2} \mathrm{O}$ content of in situ, 
granitic partial melts. This paper presents data which highlight the genetic relationship between the variability of fluid-present/-absent conditions and the operation of wellestablished metamorphic and melting reactions. The data support the notion that the fluid regime is internally controlled and there is little or no influence from externally derived fluids.

\section{Geological Context}

The Etive igneous complex (Fig. 1) is one of several composite, post-orogenic, calcalkaline intrusions of Silurian-Devonian age in the western Scottish Highlands. The Etive Complex formed as a result of successive cauldron subsidences producing a series of broadly concentric intrusions (Anderson, 1937). In order of emplacement, these are the Quarry Diorite, the Cruachan Granodiorite, the Meall Odhar Granite and the Starav Adamellite (Droop \& Treloar, 1981). The igneous complex is in contact with Dalradian metasediments of the Lochaber subgroup. The emplacement temperature of the Quarry Diorite was estimated to be around $1000{ }^{\circ} \mathrm{C}$ (Moazzen \& Droop, 2005). The ensuing contact metamorphism produced an extensive, 2-km-wide, thermal aureole which was delineated on the basis of mapping metamorphic index minerals (Droop \& Moazzen, 2007). The effects of contact metamorphism are particularly evident within the predominantly pelitic Leven Schist and pelitic units of the Islay Quartzite to the south of the complex in the vicinity of Loch Awe. The most abundant rocks in the southern aureole are pelitic and semi-pelitic hornfelses, which preserve systematic changes in the mineral assemblages from $\mathrm{Qtz}+\mathrm{Ms} \pm \mathrm{Bt} \pm \mathrm{Chl}$ (abbreviations from Kretz, 1983) up to a variety of high-grade assemblages involving, progressively, cordierite (zone II), andalusite $+\mathrm{K}$-feldspar (zone III), corundum (zone IV), spinel (zone V) and sillimanite (zone VI) (Moazzen et al., 2001; Droop \& Moazzen, 2007). Cordierite is present and modally abundant in all assemblages upgrade of zone I. Many of the metamorphic reactions developed in quartz-bearing pelites and semi-pelites downgrade of zone IV consumed quartz, leading to the development of quartz-absent assemblages in rocks of suitable composition (cf. Pattison \& Harte, 1985). For example, the andalusite $+\mathrm{K}-$ feldspar isograd records the reaction: $\mathrm{Ms}+\mathrm{Qtz}=\mathrm{And}+\mathrm{Kfs}+\mathrm{H}_{2} \mathrm{O}_{(1)}$ In many rocks, reaction (1) resulted in the disappearance of muscovite, but in muscovite-rich, quartz- 
poor rocks, reaction (1) resulted in the total consumption of quartz. Muscovite persisting to higher grade in such rocks underwent the dehydration reaction:

$\mathrm{Ms}=\mathrm{Crn}+\mathrm{Kfs}+\mathrm{H}_{2} \mathrm{O}_{(2)}$ which was responsible for the corundum isograd. The appearance of spinel in zone V suggests the KFMASH model univariant reaction: $\mathrm{Bt}+\mathrm{And}=\mathrm{Spl}+\mathrm{Crn}+\mathrm{Crd}+\mathrm{Kfs}+\mathrm{H}_{2} \mathrm{O}_{(3)}$ The sillimanite isograd is marked by the onset of direct replacement of andalusite by sillimanite: And = Sil.(4) No fibrolitic sillimanite was detected in any of the samples studied by Droop \& Moazzen (2007). Vernon (1979) has argued that fluid presence is necessary for the production of fibrolite. The absence of fibrolite in the Sillimanite Zone is consistent with the likely absence of a discrete aqueous fluid at the highest grades of contact metamorphism (Droop \& Moazzen, 2007). Complete replacement of andalusite by sillimanite is achieved only within $\approx 5 \mathrm{~m}$ of the igneous contact.

Migmatites, with both agmatic and stromatic structures, first appear within quartz-present assemblages of the Spinel Zone. The mesosomes consist of cordierite-rich pelitic and semi-pelitic hornfels. The leucosomes generally form thin ( $<2 \mathrm{~mm}$ thick) foliationparallel K-feldspar + quartz segregations and discrete crosscutting, igneous-textured Kfeldspar + quartz + plagioclase veins; the latter are mostly $<5 \mathrm{~mm}$ thick but some rare veins measure up to $12 \mathrm{~mm}$ thick. Both types of leucosome are characterized by blocky, sub-/euhedral K-feldspar crystals that are coarser-grained than the mesosomes and are separated by cuspate, interstitial patches of quartz (e.g. Vernon \& Collins, 1988; Sawyer, 1999). Pattison \& Harte (1988) interpreted similar veins at Ballachulish to be crystallized segregations of anatectic melt. In the Etive aureole, vein leucosomes appear locally immediately upgrade of the spinel isograd, but foliation-parallel leucosomes first appear approximately $150 \mathrm{~m}$ into the spinel zone. The foliation-parallel leucosomes are interpreted as in situ partial melt segregations, and the vein leucosomes as mobilized melt. The part of zone $\mathrm{V}$ characterized by the development, in some rocks, of foliationparallel leucosomes will be referred to hereafter as the 'Upper Spinel Zone', whereas the part without foliation-parallel leucosomes will be referred to as the 'Lower Spinel Zone'. Droop \& Moazzen (2007) suggested that the first melting reaction was the watersaturated, congruent reaction: $\mathrm{Bt}+\mathrm{Crd} \pm \mathrm{And}+\mathrm{Kfs}+\mathrm{Pl}+\mathrm{Qtz}+\mathrm{H}_{2} \mathrm{O}=\operatorname{melt}(5)$ As 
all of these solid phases persist at higher grades it is therefore reasonable to assume that they were not consumed by the progression of reaction (5). The majority of metamorphic reactions up to the onset of partial melting are $\mathrm{H}_{2} \mathrm{O}$-producing, dehydration reactions. The subsolidus system is thus likely to have been fluid-saturated, considering that the porosities of high-grade metamorphic rocks are typically very low (e.g. Rutter \& Brodie, 1985). The limiting phase is thus likely to have been aqueous fluid. If reaction (5) consumed all available water, subsequent melting reactions must have been waterundersaturated. The presence of rare contact metamorphic garnet in leucosomes of quartz-bearing pelites in zone VI led Droop \& Moazzen (2007) to suggest the operation of the following fluid-absent melting reaction: $\mathrm{Bt}+\mathrm{Crd}+\mathrm{Qtz}+\mathrm{Pl}=\mathrm{Grt}+\mathrm{Kfs}+$ melt (6) Furthermore the presence of quartzofeldspathic leucosomes within otherwise quartzabsent zone VI pelites suggests the progression of the following fluid-absent melting reaction: $\mathrm{Sill}+\mathrm{Bt}=\mathrm{Spl} \pm \mathrm{Crd} \pm \mathrm{Crn} \pm \mathrm{Kfs}+$ melt $(7)$ Finally the development of euhedral orthopyroxene and cordierite within leucosomes of semi-pelitic rocks close to the igneous contact suggests the operation of the model KFMASH fluid-absent univariant reaction: $\mathrm{Bt}+\mathrm{Grt}+\mathrm{Qtz}=\mathrm{Crd}+\mathrm{Opx}+\mathrm{Kfs}+$ Melt $(8)$ Where garnet is not necessary as reactant, Droop \& Moazzen (2007) infer the operation of the following reaction: $\mathrm{Bt}+\mathrm{Pl}+\mathrm{Qtz}=\mathrm{Opx}+\mathrm{Crd}+\mathrm{Kfs}+$ melt $(9)$ The fractured and breccia-like nature of many migmatitic rocks provides further evidence for the operation of fluid-absent melting reactions. Fluid-present melting reactions have a negative $\Delta V$ and are unable to cause rocks to fracture, unless there is an influx of externally derived water. On the other hand, fluid-absent melting reactions have a positive $\Delta V$, and are able to induce fracturing (Clemens \& Droop, 1998).

Droop \& Treloar (1981) calculated pressures of contact metamorphism in the southern section of the thermal aureole using an internally consistent data set derived from published phase equilibria. Calculated pressures were found to lie within the range 1.0 to $2.0 \mathrm{kbar}$, corresponding to 3 to $6 \mathrm{~km}$ of overburden during the intrusion. Moazzen et al. (2001) obtained updated thermobarometric estimates by applying fluid-conservative equilibria to samples from zones III, V and VI. The calculated temperatures ranged from $575^{\circ} \mathrm{C}$ in zone III to $850{ }^{\circ} \mathrm{C}$ in the upper zone VI. Calculated pressures clustered around 
2 kbar, in good agreement with those deduced by earlier by Droop \& Treloar (1981). Recently, Droop \& Moazzen (2007) refined the thermobarometric estimates using a combination of conventional thermobarometry and THERMOCALC modelling. Isograd reactions can generally be modelled satisfactorily in the CNKFMASH system as an isobaric sequence at $2.2 \mathrm{kbar}$. An exception is the spinel isograd which occurs at anomalously low- $T$ because of the partitioning of $\mathrm{Zn}$ into spinel. Estimated isograd temperatures for the And $+\mathrm{Kfs}$, Crn, Spl, melt and Sil isograds are $610,630,660,680$ and $705^{\circ} \mathrm{C}$, respectively.

\section{Samples and Analytical Techniques}

Thirty-four representative cordierite-bearing samples were obtained from field work and from existing collections including those of Droop \& Treloar (1981), Moazzen (1999), Moazzen et al. (2001) and Droop \& Moazzen (2007). Each sample was subjected to standard petrographical analysis in order to obtain a representative suite of rocks that encompassed the following key points: (i) cordierite is modally abundant, fresh, unaltered and relatively inclusion-free; and (ii) samples that reflect a range of mineral assemblages and bulk-rock compositions which are diagnostic of each metamorphic zone. The first of these points is the most crucial to obtain reliable $\mathrm{H}_{2} \mathrm{O}$ and $\mathrm{CO}_{2}$ contents from cordierite; consequently, low-grade, inclusion-rich, predominantly altered cordierite from zone II have been omitted. The diagnostic mineral assemblages and metamorphic zones of each sample investigated in this study are presented in the Appendix. The reader is referred to the paper by Droop \& Moazzen (2007) for a detailed petrological analysis of the samples studied.

\section{FTIR}

Fourier-transform infrared spectroscopy is a powerful tool for determining the $\mathrm{H}_{2} \mathrm{O}$ and $\mathrm{CO}_{2}$ contents of cordierite (e.g. Vry et al., 1990; Kalt, 2000). Molecular water, hydrocarbons and $\mathrm{CO}_{2}$ are easily resolved in interference-free sections of the infra-red (IR) spectrum (Farrell \& Newnham, 1967; Wood \& Nassau, 1967; Goldman et al., 1977; Aines \& Rossman, 1984). Water molecules are distributed in sites close to the sixmembered rings and are found to be oriented in the $\left(\begin{array}{lll}1 & 0 & 0\end{array}\right)$ plane (Farrell \& Newnham, 
1967; Wood \& Nassau, 1967; Cohen et al., 1977). Goldman et al. (1977) identified two types of $\mathrm{H}_{2} \mathrm{O}$ in the $\left(\begin{array}{lll}1 & 0 & 0\end{array}\right)$ plane. Type $\mathrm{I}_{2} \mathrm{O}$ is aligned with the $\mathrm{H}-\mathrm{H}$ vector along the channels, parallel to the $c$-axis. Additionally, water was found in the $\left(\begin{array}{lll}1 & 0 & 0\end{array}\right)$ plane, with its $\mathrm{H}-\mathrm{H}$ vector parallel to the $b$-axis - hereafter, known as type $\mathrm{II}_{2} \mathrm{O}$. Small amounts of alkali atoms were also detected occupying the centres of the six-membered rings $\left(\begin{array}{lll}0 & 0 & 0\end{array}\right)$. The amount of type II $\mathrm{H}_{2} \mathrm{O}$ is commonly found to be correlated with the number of cations in the channels. The cations (mainly $\mathrm{Na}^{+}$) cause a local charge imbalance resulting in the rotation of the type I water molecules by $90^{\circ}$, thus forming the type II water molecule. Goldman et al. (1977) suggested that the presence of one channel cation would control the orientation of two water molecules. Recent infrared and Raman spectroscopic studies have revealed the presence of $\mathrm{H}_{2} \mathrm{O}$ aligned with its $\mathrm{H}-\mathrm{H}$ vector parallel to the $a$-axis of cordierite, but not interacting with alkali cations (Kolesov \& Geiger, 2000). The linear $\mathrm{CO}_{2}$ molecule is aligned with its long axis perpendicular to the channels and parallel to the cordierite $a$-axis (Goldman et al., 1977; Armbruster \& Bloss 1982).

The spectra obtained from fresh cordierite are remarkably 'clean', with excellent peak-tobackground ratios and extremely flat baselines (Fig. 2). $\mathrm{CO}_{2}$ is resolved near $2349 \mathrm{~cm}^{-1}$, and peaks caused by asymmetric stretching $\left(v_{3}\right)$ of $\mathrm{H}_{2} \mathrm{O}$ molecules occur at approximately $3689 \mathrm{~cm}^{-1}$ for type I water $\left(\mathrm{H}_{2} \mathrm{O} \mathrm{I} v_{3}\right)$, and $3632 \mathrm{~cm}^{-1}$ for type II water $\left(\mathrm{H}_{2} \mathrm{O} \mathrm{II} v_{3}\right)$. Symmetric stretching $\left(v_{1}\right)$ peaks occur near $3574 \mathrm{~cm}^{-1}\left(\mathrm{H}_{2} \mathrm{O}\right.$ II $\left.v_{1}\right)$ and bending $\left(v_{2}\right)$ at $1630 \mathrm{~cm}^{-1}$.

The water and $\mathrm{CO}_{2}$ content of cordierite from numerous samples were determined by high-resolution FTIR, using the Bruker HS 102 machine at the Geo-institute in Bayreuth. The HS 102 is set with an optical microscope, a GLOBAR mid-infrared source, a $\mathrm{He}-\mathrm{Ne}$ laser-controlled movable mirror, a $\mathrm{KBr}-\mathrm{Ga}$ beam splitter and an MCT detector. The spectra were collected in situ from approximately $100-\mu \mathrm{m}$-thick, double-polished thin sections. Two hundred scans were run per analysis using a beam diameter of 15-20 $\mu \mathrm{m}$. Blanks were run once per hour and backgrounds were uniformly subtracted as standard from all spectra. The infrared working curve for $\mathrm{H}_{2} \mathrm{O}$ was calibrated using cordierite of 
known composition. The $\mathrm{CO}_{2}$ and $\mathrm{H}_{2} \mathrm{O}$ content of each standard from the calibration was determined independently via stepped heating mass spectrometry (SHMS) and the $\mathrm{H}_{2} \mathrm{O}$ contents were verified independently by Karl-Fischer titration (Rigby, 2006). The $\mathrm{H}_{2} \mathrm{O}$ working curve is a plot of measured peak-height absorbance $v$. the independently determined $\mathrm{H}_{2} \mathrm{O}$ content. The $\mathrm{H}_{2} \mathrm{O}$ peak height absorbance was highly reproducible, yielding a calibration curve with an excellent fit. In order to check the validity of the calibration further, the mineral standard AMNH (used by Carrington \& Harley, 1996; Kalt, 2000; Thompson et al., 2001; Harley et al., 2002) has $X_{\mathrm{Mg}}=0.87$; $\mathrm{H}_{2} \mathrm{O}=1.56 \pm 0.08 \mathrm{wt} \%$; and $\mathrm{CO}_{2}=0.66 \pm 0.05 \mathrm{wt} \%$ ), whose $\mathrm{H}_{2} \mathrm{O}$ and $\mathrm{CO}_{2}$ content had been determined independently via SHMS, was analysed and found to be in excellent agreement with the other standards. The working curve was used in all analyses of cordierite to convert peak height absorbance to wt $\% \mathrm{H}_{2} \mathrm{O}$. The $\mathrm{CO}_{2}$ working curve of Vry et al. (1990) was used to calculate the $\mathrm{wt} \% \mathrm{CO}_{2}$ from the measured peak height absorbance. Vry et al. (1990) measured absorbance from $280-\mu \mathrm{m}$-thick pellets that consisted of $1 / 34$ cordierite and $33 / 34 \mathrm{KBr}$, therefore absorbance was recalculated to $100 \%$ cordierite and 100- $\mu$ m-thick sections. Kalt (2000) analysed several well-known $\mathrm{CO}_{2}$ cordierite standards via FTIR in order to check the applicability of the Vry et al. (1990) calibration. These FTIR-determined results were in good agreement with independently determined $\mathrm{CO}_{2}$ concentrations, thereby demonstrating that the Vry et al. (1990) calibration is valid and applicable.

All analyses were taken from cordierite domains that were inclusion-free and distant from cracks and alteration. $\mathrm{H}_{2} \mathrm{O}$ and $\mathrm{CO}_{2}$ contents were calculated from several grains in each sample. Methane is infrared-active; however, it was not detected in any of the samples. Errors in $\mathrm{wt} \% \mathrm{CO}_{2}$ and $\mathrm{H}_{2} \mathrm{O}$ were calculated using standard error propagation techniques, incorporating the uncertainty in the analytical population and the calibration. Measured $\mathrm{CO}_{2}$ and $\mathrm{H}_{2} \mathrm{O}$ were converted to values of the molecular coefficients $n$ and $m$ using the major element composition of each cordierite (Table 1). Major element compositions of cordierite were determined by wavelength-dispersive spectrometry (WDS) using a CAMECA SX-100 electron microprobe at an accelerating voltage of $15 \mathrm{kV}$ with a beam 
current of $20 \mathrm{nA}$. Concentrations were calculated from relative peak intensities using the internal PAP-correction software of Pouchou \& Pichoir (1991).

\section{Cordierite Volatile Contents}

\section{$\mathrm{H}_{2} \mathrm{O}$ contents}

The average $\mathrm{H}_{2} \mathrm{O}$ contents of cordierite range from 0.836 to $1.490 \mathrm{wt} \%$ (Table 2).

Generally, the tight intra-sample clustering of cordierite $\mathrm{H}_{2} \mathrm{O}$ contents measured from a variety of grain sizes indicates that retrograde diffusion was minimal and a high degree of equilibration was attained. Single grains typically show only minor heterogeneity in total $\mathrm{H}_{2} \mathrm{O}$ contents (Fig. 3). There is no systematic difference in the total $\mathrm{H}_{2} \mathrm{O}$ content of cordierite from cores and rims except for one sample - MM171 (Fig. 4). A comprehensive study totalling 40 spot analyses was conducted in order to further investigate the potential of zoning in other grains from this sample. Of a further 12 grains analysed only one more was found to be zoned. Although intra-sample variation is generally small, there is considerable variation in the total $\mathrm{H}_{2} \mathrm{O}(\mathrm{wt} \%)$ between samples across the thermal aureole. Figure 5 illustrates the variation in total $\mathrm{H}_{2} \mathrm{O}(\mathrm{wt} \%)$ across the thermal aureole.

Samples from the middle aureole, designated to include the Andalusite + K-feldspar Zone, the Corundum Zone and the Lower Spinel Zone, contain total $\mathrm{H}_{2} \mathrm{O}$ contents between 1.34 and $1.46 \mathrm{wt} \%$. Samples from the inner aureole, designated to include the Upper Spinel Zone (upgrade of the melt-in isograd) and the Sillimanite Zone, contain slightly lower total $\mathrm{H}_{2} \mathrm{O}$ contents $(1.2-0.8 \mathrm{wt} \%)$. There appears to be a gradual decrease in the total $\mathrm{H}_{2} \mathrm{O}$ contents beyond the melt-in isograd. The lowest recorded total $\mathrm{H}_{2} \mathrm{O}$ contents occur in the Sillimanite Zone, approximately $70 \mathrm{~m}$ from the igneous contact. Samples from within $30 \mathrm{~m}$ of the igneous contact and two xenoliths from within the Quarry Diorite yield moderate $\mathrm{H}_{2} \mathrm{O}$ contents $(0.984-1.263 \mathrm{wt} \%)$ that do not differ significantly from those in the Upper Spinel zone.

The relative abundance of type I to type $\mathrm{II}_{2} \mathrm{O}$ also varies systematically across the thermal aureole. Of the analysed samples MD1 is one of the furthest from the igneous 
contact, approximately $950 \mathrm{~m}$, and contains type I and type II $\mathrm{H}_{2} \mathrm{O}$ in roughly equal proportions. Conversely, sample MM194B, approximately $110 \mathrm{~m}$ from the contact, has twice as much type I than type $\mathrm{II}_{2} \mathrm{O}$ (Fig. 6). The total channel cation contents in cordierite from the Etive thermal aureole are found to correlate reasonably well with measured type II $\mathrm{H}_{2} \mathrm{O}$ contents (Fig. 7) and the relative decrease in type $\mathrm{II}_{2} \mathrm{O}$ is broadly consistent with an observed decrease in the total channel cation content as temperature increases (Fig. 8).

\section{$\mathrm{CO}_{2}$ contents}

The average $\mathrm{CO}_{2}$ contents of cordierite range from 0.07 to $0.23 \mathrm{wt} \%$ (Table 2). The $1 \sigma$ deviations for average $\mathrm{CO}_{2}$ contents in some samples are significantly larger than those for water, suggesting that there may be significant inter-granular variation. Zoning profiles through large single grains suggest there is little intra-granular variation. Average $\mathrm{CO}_{2}$ contents across the thermal aureole show only minor variation (Fig. 9). Samples MD9B, MD9A (pelitic xenoliths) and MM193Y (a sample from within $3 \mathrm{~m}$ of the igneous contact) yield $\mathrm{CO}_{2}$ contents two to three times greater than samples from elsewhere in the aureole.

\section{FTIR v. SIMS}

Seven of the 34 cordierite-bearing samples analysed by FTIR in the study have been the subject of a preliminary study by Moazzen et al. (2001) who used SIMS. There is generally a good agreement between the SIMS results of Moazzen et al. (2001), and the FTIR results from this study (Fig. 10). There is, however, a rather large and crucial discrepancy between the FTIR results and SIMS results for sample MM171.

Fourier-transform infrared spectroscopy analysis in this study revealed that zoning was apparent in a couple of grains within this sample. The measured values in the cores of these zoning profiles are between 1.30 and $1.42 \mathrm{wt} \% \mathrm{H}_{2} \mathrm{O}$. These 'core' values are in agreement with the SIMS data, but the overall FTIR-determined $\mathrm{H}_{2} \mathrm{O}$ content (calculated from the mean of 45 analyses) equates to a much lower value (1.16 wt\%). Considering the greater number of analyses performed in this study and the relationship of this sample 
to the overall trend in $\mathrm{H}_{2} \mathrm{O}$ contents across the aureole it seems plausible to favour the FTIR results.

Furthermore, there is disagreement between the mean $\mathrm{H}_{2} \mathrm{O}$ contents determined for sample MD9a. FTIR analysis from this study reveals that sample MD9a has variable $\mathrm{H}_{2} \mathrm{O}$ contents and large but similarly variable $\mathrm{CO}_{2}$ contents. However, Moazzen et al. (2001) was unable to quantify $\mathrm{CO}_{2}$ on the SIMS as their background level was $0.322 \mathrm{wt} \%$. Variable $\mathrm{CO}_{2}$ contents will effectively reduce the amount of $\mathrm{H}_{2} \mathrm{O}$ which can be housed within cordierite channels. $\mathrm{CO}_{2}$-rich cordierite tends to be relatively $\mathrm{H}_{2} \mathrm{O}$-poor and vice versa. The large intra-sample variations in $\mathrm{H}_{2} \mathrm{O}$ and $\mathrm{CO}_{2}$, coupled with a lack of SIMSdetermined $\mathrm{CO}_{2}$ data adequately explains the disparity between the two data sets. The analysis of even minor $\mathrm{CO}_{2}$ is crucial in order to determine accurately fluid-present $v$. fluid-absent conditions via the robust thermodynamic modelling and fluid saturation curves of Harley \& Carrington (2001), Thompson et al. (2001) and Harley et al. (2002). As $\mathrm{CO}_{2}$ could be quantified in this study and FTIR is relatively rapid and cheap in comparison with SIMS it seems logical to favour our approach.

\section{Fluid Conditions and Cordierte Volatile Saturation}

\section{Thermodynamic methods}

While the majority of samples are predominantly $\mathrm{H}_{2} \mathrm{O}$-bearing, small but significant amounts of $\mathrm{CO}_{2}$ are present in all rocks. Cordierite that would be classed as 'fluidundersaturated' in the $\mathrm{H}_{2} \mathrm{O}$-only system, may actually approach fluid saturation in the $\mathrm{H}_{2} \mathrm{O}-\mathrm{CO}_{2}$ system. Similarly, $\mathrm{CO}_{2}$-undersaturated cordierite may approach fluid saturation in the $\mathrm{H}_{2} \mathrm{O}-\mathrm{CO}_{2}$ system. Consequently, it is imperative to calculate $\mathrm{H}_{2} \mathrm{O}-\mathrm{CO}_{2}$ cordierite volatile saturation surfaces for each individual sample at the appropriate $P-T$ conditions of formation. The approach of Harley et al. (2002) has been adopted to calculate individual $\mathrm{H}_{2} \mathrm{O}-\mathrm{CO}_{2}$ saturation surfaces. Mean total volatile contents of cordierite $(n+m)$ for each sample are compared with modelled $\mathrm{H}_{2} \mathrm{O}-\mathrm{CO}_{2}$ saturation surfaces at the $P-T$ of interest. Fluid-present conditions are inferred if the mean total volatile content (incorporating error in the analysis and $P-T$ conditions) intersects the total volatile saturation curve at the temperature of interest. Conversely, fluid-absent conditions are 
inferred if the mean total volatile content does not intersect the saturation curve at the temperature of interest. $\mathrm{H}_{2} \mathrm{O}$ and $\mathrm{CO}_{2}$ activities were calculated using the thermodynamic methods of Harley \& Carrington (2001) and Thompson et al. (2001), respectively (Table 3).

The peak metamorphic pressure estimate applied to each sample was $2.2 \mathrm{kbar}$ (Droop \& Moazzen, 2007). Peak temperature estimates for each sample were based upon data from Droop \& Moazzen (2007). The following are considered the best estimates of isograd temperatures: andalusite $+\mathrm{K}$-feldspar isograd: $610^{\circ} \mathrm{C}$; corundum isograd: $630{ }^{\circ} \mathrm{C}$; spinel isograd: $660^{\circ} \mathrm{C}$; melt isograd: $680{ }^{\circ} \mathrm{C}$; sillimanite isograd: $705^{\circ} \mathrm{C}$; contact with Quarry Diorite: $800^{\circ} \mathrm{C}$. Temperature estimates for individual aureole samples (Table 2) were obtained by interpolation, scaled in accordance with the relative distances upgrade and downgrade to the nearest respective isograds in a direction approximately perpendicular to the igneous contact. A temperature of $1000^{\circ} \mathrm{C}$ was assumed for xenolith samples in accordance with the magmatic temperature estimate of Moazzen \& Droop (2005). The $1 \sigma$ uncertainties for activity values were calculated using standard error propagation techniques incorporating the error in the analytical population, thermodynamic data and estimated uncertainties of $\pm 0.5 \mathrm{kbar}$ and $\pm 30^{\circ} \mathrm{C}$ on the $P-T$ conditions of metamorphism. Measured $\mathrm{H}_{2} \mathrm{O}$ contents $(n)$, expressed in terms of the number of molecules per formula unit (pfu) are compared with a modelled $\mathrm{H}_{2} \mathrm{O}$-saturation surface which was calculated using the thermodynamic methods of Harley et al. (2002) for the $P-T$ conditions relevant to this study.

\section{Results}

\section{Andalusite + K-feldspar and Lower Spinel Zones}

In the middle aureole, downgrade of the melt-in isograd, cordierite is characterized by consistently high $\mathrm{H}_{2} \mathrm{O}$ contents (1.36-1.46 wt\%) and low $\mathrm{CO}_{2}$ contents $(0.07-0.11 \mathrm{wt} \%)$. For estimated $P-T$ conditions these volatile contents yield high $a \mathrm{H}_{2} \mathrm{O}(0.892-1.119)$ and low $a \mathrm{CO}_{2}(0.080-0.147)$ values (Table 3). A comparison of the mean $n \mathrm{H}_{2} \mathrm{O}$ with the $\mathrm{H}_{2} \mathrm{O}$-only saturation curve modelled at $2.2 \mathrm{kbar}$ and various temperatures illustrates that all middle aureole samples are, within error, $\mathrm{H}_{2} \mathrm{O}$-saturated (Fig. 11). Moreover, a 
comparison of the mean total volatile contents with modelled $\mathrm{H}_{2} \mathrm{O}-\mathrm{CO}_{2}$ saturation surfaces (Fig. 12) reveals that all samples plot above, or at least very close to, the total volatile saturation curve at the $P-T$ of interest.

\section{The Upper Spinel Zone}

Quartz-absent Upper Spinel Zone samples (beyond the onset of partial melting in quartzpresent lithologies) yield calculated $a \mathrm{H}_{2} \mathrm{O}$ values between 0.643 and 0.810 (Table 3 ). Measured values of $n$ plot below the modelled $2.2 \mathrm{kbar} \mathrm{H}_{2} \mathrm{O}$-only saturation surface (Fig. 11), implying that cordierite-bearing rocks were $\mathrm{H}_{2} \mathrm{O}$-undersaturated. Upgrade, as melting proceeds, the samples become progressively more $\mathrm{H}_{2} \mathrm{O}$-undersaturated. In spite of this, a comparison of the mean total volatile content to $\mathrm{H}_{2} \mathrm{O}-\mathrm{CO}_{2}$ saturation surfaces at the $P-T$ of interest reveals that Upper Spinel Zone samples are predominantly fluidsaturated (Fig. 13). The only exception is the highest grade sample from this zone (MM144) whose total volatile contents imply that fluid-absent conditions were attained.

\section{The Sillimanite Zone}

The majority of Sillimanite Zone samples $>30 \mathrm{~m}$ from the igneous contact yield low to moderate calculated $a \mathrm{H}_{2} \mathrm{O}(0.512-0.704)$ and typically low $a \mathrm{CO}_{2}$ values $(0.100-0.166)$ (Table 3). All samples have measured values of $n$ that plot below the modelled $2.2 \mathrm{kbar}$ $\mathrm{H}_{2} \mathrm{O}$-only saturation surface (Fig. 11). Even taking into account the maximum error in the analysis, samples still do not intersect the saturation of curve of interest, implying that cordierite-bearing rocks are $\mathrm{H}_{2} \mathrm{O}$-undersaturated. Moreover, these samples plot well below the modelled $\mathrm{H}_{2} \mathrm{O}-\mathrm{CO}_{2}$ saturation surfaces at the temperature of interest, implying that fluid-undersaturated conditions prevailed (Fig. 14). Immediately adjacent to the igneous intrusion (within $30 \mathrm{~m}$ ) $a \mathrm{H}_{2} \mathrm{O}$ values rise again (0.680-1.783) and calculated $a \mathrm{CO}_{2}$ values vary from 0.139 to 0.641 . The unusually high $a \mathrm{H}_{2} \mathrm{O}$ and $a \mathrm{CO}_{2}$ values are restricted to samples within $3 \mathrm{~m}$ of the igneous contact. Samples within $3 \mathrm{~m}$ plot above modelled $\mathrm{H}_{2} \mathrm{O}-\mathrm{CO}_{2}$ saturation surfaces, implying either fluid-saturation or oversaturation with respect to their $P-T$ conditions of equilibration. Explanations for the increase in $a \mathrm{CO}_{2}$ and the unrealistic $a \mathrm{H}_{2} \mathrm{O}$ values are outlined below. 


\section{Melt- $\mathrm{H}_{2} \mathrm{O}$ contents}

In high-grade melt-bearing samples, the $\mathrm{H}_{2} \mathrm{O}$ content of the coexisting granitic melt has been calculated (Table 4) from the measured cordierite $\mathrm{H}_{2} \mathrm{O}$ content using the $D_{w}$ relationships of Harley \& Carrington (2001). The resulting data are compared with experimentally determined minimum and maximum $\mathrm{H}_{2} \mathrm{O}$ contents of granitic melt at $2 \mathrm{kbar}$ and various temperatures (Fig. 15). The experimental data set used in this comparison is that of Johannes \& Holtz (1996). Samples close to the melt-in isograd (within $20^{\circ} \mathrm{C}$ ) yield melt $\mathrm{H}_{2} \mathrm{O}$ contents that plot within error of the maximum solubility curve of Johannes \& Holtz (1996), further supporting the notion that initial melting was fluid-saturated. Sillimanite Zone samples up to within $30 \mathrm{~m}$ of the igneous contact yield melt $\mathrm{H}_{2} \mathrm{O}$ contents that vary from 3.47 to $4.47 \mathrm{wt} \%$. These values commonly plot on, or at least very close to the minimum solubility curve, which further supports the notion of a fluid-absent melting regime. Samples within $30 \mathrm{~m}$ of the igneous contact at temperatures in excess of $790^{\circ} \mathrm{C}$ plot on or above the maximum solubility curve of Johannes \& Holtz (1996).

\section{Fluid activities and volatile saturation}

In the And + Kfs Zone and the Lower Spinel Zone, down-grade of the melt-in isograd, cordierite is characterized by consistently high $\mathrm{H}_{2} \mathrm{O}$ contents $(1.36-1.46 \mathrm{wt} \%)$ and low $\mathrm{CO}_{2}$ contents $(0.07-0.11 \mathrm{wt} \%)$. For estimated $P-T$ conditions, these volatile contents yield high $a \mathrm{H}_{2} \mathrm{O}$ (within error of unity) and low $a \mathrm{CO}_{2}$ values. The small $\mathrm{CO}_{2}$ contents argue against any significant influx of externally derived $\mathrm{CO}_{2}$-rich fluids. Whereas the country rocks are non-graphite-bearing, it is reasonable to assume that a small but finite amount of organic material would have been present in the original sedimentary protolith. The subsequent heating and oxidation of minor organic debris would have generated the small amounts of $\mathrm{CO}_{2}$ present in the sample. The absence of detectable methane, the low $a \mathrm{CO}_{2}$ and high $a \mathrm{H}_{2} \mathrm{O}$ values suggest that the outer aureole samples crystallized in the presence of a predominantly aqueous fluid. The metamorphic reactions that are thought to operate in the middle aureole (e.g. reactions $1,2 \& 3$ ) are dehydration reactions. The progression of such reactions would provide a means for generating substantial amounts of $\mathrm{H}_{2} \mathrm{O}$ which, in the absence of any external modification, would saturate the 
surrounding country rocks. A comparison of the mean $n \mathrm{H}_{2} \mathrm{O}$ with the $\mathrm{H}_{2} \mathrm{O}$-only saturation curve modelled at $2.2 \mathrm{kbar}$ and various temperatures illustrates that all middleaureole samples are $\mathrm{H}_{2} \mathrm{O}$-saturated, within error. Moreover, a comparison of the mean total volatile contents with modelled $\mathrm{H}_{2} \mathrm{O}-\mathrm{CO}_{2}$ saturation surfaces reveals that all samples intersect the total volatile saturation curve at the $P-T$ of interest. This implies that fluid-saturated conditions prevailed.

The Upper Spinel Zone (up-grade of the melt-in isograd) is characterized by moderate $\mathrm{H}_{2} \mathrm{O}$ contents (1.2-0.8 wt \%) and low $\mathrm{CO}_{2}$ contents $(0.07-0.12 \mathrm{wt} \%)$. Calculated $a \mathrm{CO}_{2}$ values are relatively low but show a slight increase up-grade. Conversely, $a \mathrm{H}_{2} \mathrm{O}$ steadily decreases up-grade, from high to moderate values (Fig. 16) along with the total volatile content $(n+m)$ (Fig. 13). Measured values of $n(0.473-0.484)$ at the onset of partial melting plot within error of the $\mathrm{H}_{2} \mathrm{O}$-only saturation curve, suggesting that initial melting was $\mathrm{H}_{2} \mathrm{O}$-saturated (Fig. 11). Up-grade of the melt-in isograd all remaining Upper Spinel Zone samples have $n$ values ranging from 0.359 to 0.425 which plot below the saturation curve, implying that $\mathrm{H}_{2} \mathrm{O}$-undersaturated conditions prevailed. However, a comparison of the mean total volatile content to $\mathrm{H}_{2} \mathrm{O}-\mathrm{CO}_{2}$ saturation surfaces at the $P-T$ of interest actually reveals that all Upper Spinel Zone samples but MM144 are strictly, within error, fluid-saturated.

The operation of melting reaction (5) could theoretically provide a mechanism for consuming water, establishing fluid-undersaturated conditions and reducing $a \mathrm{H}_{2} \mathrm{O}$ beyond the onset of partial melting. All Upper Spinel Zone samples lie within an area where at least quartz-bearing samples have begun to melt. The absence of cordierite volatile data from quartz-bearing Upper Spinel Zone samples actually prevents the extent of fluid-present melting to be assessed directly in these rocks. There is no secure petrographic evidence that Upper Spinel Zone quartz-absent rocks have actually begun to melt because, although some contain foliation-parallel leucosomes, it is difficult to be sure that these do not represent very thin quartz-bearing beds or microlithons. In the absence of $\mathrm{H}_{2} \mathrm{O}$-present melting, at Upper Spinel Zone temperatures, quartz-absent rocks would still have been undergoing dehydration via reaction (3). Therefore, quartz-absent 
rocks should be $\mathrm{H}_{2} \mathrm{O}$-saturated and have $a \mathrm{H}_{2} \mathrm{O}$ values close to unity, analogous to the majority of samples in the middle aureole. Reaction (3) is a dehydration reaction that was proceeding in quartz-absent rocks simultaneously with a water-consuming melting reaction in quartz-present rocks. It is possible that dehydrating quartz-absent rocks provided water to flux melting in nearby quartz-present rocks (cf. Pattison \& Harte, 1988). This could provide a mechanism for promoting a reduction in the $a \mathrm{H}_{2} \mathrm{O}$ in rocks that have not themselves undergone partial melting. This may suggest that dehydration reaction (3) was, in part, driven by a chemical potential gradient caused by the consumption of $\mathrm{H}_{2} \mathrm{O}$ via melting in nearby quartz-present rocks, and in turn, the consequent migration of $\mathrm{H}_{2} \mathrm{O}$ led to more melting (cf. Pattison \& Harte, 1988). Theoretically, the reduction in $a \mathrm{H}_{2} \mathrm{O}$ and the lack of available free water for melting implies that any coexisting granitic melt will be $\mathrm{H}_{2} \mathrm{O}$-undersaturated; the cordierite $\mathrm{H}_{2} \mathrm{O}$ content will re-equilibrate to $\mathrm{H}_{2} \mathrm{O}$-undersaturated compositions that are compatible with that of any coexisting $\mathrm{H}_{2} \mathrm{O}$-undersaturated melt (Stevens et al., 1995; Carrington \& Harley, 1996; Harley \& Carrington, 2001; Harley et al., 2002). The estimated $\mathrm{H}_{2} \mathrm{O}$ contents of granitic melt coexisting with cordierite in the Upper Spinel Zone range from 4.15 to $6.17 \mathrm{wt} \%$. The estimated melt $\mathrm{H}_{2} \mathrm{O}$ contents are in agreement with experimentally determined $\mathrm{H}_{2} \mathrm{O}$ contents for granitic melt of minimum or eutectic composition at $2 \mathrm{kbar}$ (Holtz \& Johannes, 1994; Johannes \& Holtz, 1996). The lowest grade Upper Spinel Zone samples yield melt $\mathrm{H}_{2} \mathrm{O}$ contents that are close to saturation and hence imply fluidpresent melting, whereas the highest grade samples yield melt $\mathrm{H}_{2} \mathrm{O}$ contents close to the minimum and imply that fluid-absent conditions prevailed (Fig. 15).

Proceeding up-grade into the Sillimanite Zone, even quartz-absent rocks have begun to melt, as testified by igneous-textured cordierite-rich domains and segregations. A gradual decrease in the calculated $a \mathrm{H}_{2} \mathrm{O}$ occurs from the melt-in isograd to well within the Sillimanite Zone (Fig. 16). If the water has been consumed by reaction (5), fluid-absent conditions and lower water activities prevail up-grade. Any further melting will be fluidabsent, and the values of water activity (in the melt and in cordierite) will be a function of temperature. Fluid-absent melting reactions (6-8), established on independent petrological grounds, are thought to dominate in the Sillimanite Zone (Moazzen et al., 
2001; Droop \& Moazzen, 2007). The low $a \mathrm{H}_{2} \mathrm{O}$ values and low cordierite volatile contents from both quartz-present and quartz-absent Sillimanite Zone rocks, unequivocally demonstrate that fluid-absent conditions prevailed (Figs 11, $14 \& 16$ ). Even considering the most unfavourable of conditions, by taking into account the maximum errors in the analysis and $P-T$, the mean total volatile content for each sample plots well below the total volatile saturation curve at the $P-T$ conditions of formation. Estimated melt $\mathrm{H}_{2} \mathrm{O}$ contents for Sillimanite Zone samples (at distances $>30 \mathrm{~m}$ from the igneous contact) range from 4.25 to $3.75 \mathrm{wt} \%$, and are in agreement with experimentally determined $\mathrm{H}_{2} \mathrm{O}$ contents for granitic melt of minimum or eutectic composition at $2 \mathrm{kbar}$ (Johannes \& Holtz, 1996). The estimated melt $\mathrm{H}_{2} \mathrm{O}$ contents from both the Upper Spinel zone and Sillimanite Zone plot within error of the minimum $\mathrm{H}_{2} \mathrm{O}$ curve of Johannes \& Holtz (1996), implying that all melts were $\mathrm{H}_{2} \mathrm{O}$-undersaturated. The agreement between estimated melt $\mathrm{H}_{2} \mathrm{O}$ contents and experimentally determined melt $\mathrm{H}_{2} \mathrm{O}$ contents further supports the contention that Upper Spinel and Sillimanite Zone cordierite $\mathrm{H}_{2} \mathrm{O}$ contents are representative of peak metamorphic values.

The highest grade Sillimanite Zone samples yield moderate-to-high $a \mathrm{H}_{2} \mathrm{O}$ values $(0.680$ 1.783 ) and thus reflect varying degrees of $\mathrm{H}_{2} \mathrm{O}$ saturation. A comparison of the total volatile contents with modelled $\mathrm{H}_{2} \mathrm{O}-\mathrm{CO}_{2}$ saturation surfaces reveals that all samples plot, within error of fluid saturation. Samples MM198c and MM197a are strictly only slightly undersaturated. The degree of undersaturation is, however, decidedly smaller than that of Upper Spinel Zone samples that record similar $a \mathrm{H}_{2} \mathrm{O}$ values.

The two xenolith samples (MD9a \& MD9b) record $a \mathrm{H}_{2} \mathrm{O}$ values that are not possible, i.e. values which are significantly greater than unity even when considering the margins of error. The estimated melt $\mathrm{H}_{2} \mathrm{O}$ contents also yield values that are inconsistent with the available experimental data. Furthermore, samples which are within $3 \mathrm{~m}$ (MM193Y, MD9a \& MD9b) of the igneous contact yield relatively high $\mathrm{CO}_{2}$ contents and correspondingly large $a \mathrm{CO}_{2}$ values $(0.40-0.61)$. The total volatile contents $(0.377-0.472)$ for samples plot significantly above the saturation curve at the temperature of interest. The localized increase in volatiles immediately adjacent to the igneous contact is 
demonstrated in Fig. 17. There is no difference in bulk-rock chemistry that would adequately explain the localized increase in $\mathrm{CO}_{2}$, i.e. the decarbonation of graphite-rich pelites. Considering the evidence collectively and the proximity of the samples to the igneous body, the high $\mathrm{CO}_{2}$ contents and unrealistic $a \mathrm{H}_{2} \mathrm{O}$ values may be attributed to the input of magmatically derived fluids. As the Quarry Diorite cooled and crystallized, it would have expelled a free fluid phase (Moazzen et al., 2001). The over-saturation recorded in these samples may be satisfactorily explained by fact that the cordierite did not acquire its fluid content at the assumed peak of metamorphism. If one ignores the possibility of cooling and re-equilibration with an externally derived fluid at lower temperatures, then this will overestimate the $a \mathrm{H}_{2} \mathrm{O}$ and melt $\mathrm{H}_{2} \mathrm{O}$ content for the assumed peak metamorphic conditions (c.f. Harley et al., 2002).

Samples 15-30 m from the igneous contact appear to have crystallized in the presence of a predominantly aqueous fluid. On the other hand, samples immediately adjacent to the igneous contact, i.e. within $3 \mathrm{~m}$, appear to have crystallized in the presence of a $\mathrm{CO}_{2}$ $\mathrm{H}_{2} \mathrm{O}$-rich fluid. The samples immediately adjacent to the contact may have scavenged any available $\mathrm{CO}_{2}$ along with $\mathrm{H}_{2} \mathrm{O}$. If $\mathrm{CO}_{2}$ was in short supply it could potentially be exhausted, leaving only $\mathrm{H}_{2} \mathrm{O}$ to re-saturate samples further from the igneous contact. In summary, the zone of re-saturation by magmatically derived fluids is constrained to be, at least, up to $30 \mathrm{~m}$ from the igneous contact.

The results of this study are broadly consistent with the findings of the preliminary study by Moazzen et al. (2001). There are, however, a number of crucial discrepancies that have ultimately led to significant differences in the interpretations of the two data sets. A key aspect in this respect is the use of two different thermodynamic data sets to calculate water activities and infer the presence or absence of fluid. Moazzen et al. (2001) used thermodynamic parameters $\left(\Delta S^{\circ} \& \Delta H^{\circ}\right.$ values for the dehydration reaction of Mgcordierite) extracted from only the 2 kbar data of Mirwald et al. (1979), whereas the thermodynamic data of Harley et al. (2002), employed in this study, are based upon a much larger, polybaric experimental data set, and are thus likely to be more accurate. While Moazzen et al. (2001) were able to calculate $a \mathrm{H}_{2} \mathrm{O}$ values for select samples, this 
study has been able to analyse a much larger sample suite producing a host of additional information including $a \mathrm{CO}_{2}$ values, volatile $(n+m)$ saturation curves and estimates of the $\mathrm{H}_{2} \mathrm{O}$ contents of coexisting melts. The only comparisons that can be made between this study and that of Moazzen et al. (2001) thus revolve around the $a \mathrm{H}_{2} \mathrm{O}$ data. Marked differences in the two thermodynamic data sets will result in different $a \mathrm{H}_{2} \mathrm{O}$ values being calculated for essentially comparable cordierite $\mathrm{H}_{2} \mathrm{O}$ contents. In spite of this, both data sets imply that fluid-absent conditions prevailed in the Sillimanite Zone and fluid-present conditions were attained in the middle aureole.

Calculated $a \mathrm{H}_{2} \mathrm{O}$ values from Moazzen et al. (2001) suggest that wall-rock hornfelses as close as $15 \mathrm{~m}$ crystallized in the absence of fluid. Conversely, results from this study clearly demonstrate fluid-saturated conditions prevailed at distances up to $30 \mathrm{~m}$ from the igneous contact. The main difference between the two data sets revolves around Upper Spinel Zone samples. There is a rather large and crucial discrepancy between the FTIR results and SIMS results for sample MM171 which can be satisfactorily explained by the apparent zoning (Fig. 4). Moazzen et al. (2001) concluded that $\mathrm{H}_{2} \mathrm{O}$-saturated conditions prevailed in the Upper Spinel Zone. This conclusion was based solely on the results of one sample-MM171, which, as previously demonstrated may be an unreliable fluid monitor. All Upper Spinel Zone samples are $\mathrm{H}_{2} \mathrm{O}$-unsaturated. Considering the greater number of analyses conducted on sample MM171 in this study, and perhaps more importantly, the relationship of this sample to the overall trend in $\mathrm{H}_{2} \mathrm{O}$ and total volatile contents across the thermal aureole it seems reasonable to favour the FTIR results. More importantly, the determination of $\mathrm{CO}_{2}$ via FTIR in this study enabled volatile saturation curves to be calculated which indicate whether fluid-present or fluid-saturated conditions prevailed across the aureole. As pointed out by Harley et al. (2002), even small amounts of $\mathrm{CO}_{2}$ can fluid-saturate $(n+m)$ a cordierite which was previously undersaturated in the $\mathrm{H}_{2} \mathrm{O}$-only system. Taking this into account all Upper Spinel Zone samples, except MM144 are fluid-saturated. Furthermore, the agreement between estimated melt $\mathrm{H}_{2} \mathrm{O}$ contents and independently determined melt $\mathrm{H}_{2} \mathrm{O}$ contents further supports the validity of the more extensive cordierite volatile data obtained in this study. 


\section{Conclusion}

The results are compatible with the operation of an up-temperature sequence of reactions deduced on independent petrological grounds by Droop \& Moazzen (2007). This sequence involves, progressively: (i) dehydration, followed by (ii) fluid-present partial melting, followed by (iii) fluid-absent partial melting. Measured volatile contents agree well with modelled saturation surfaces, implying that fluid-saturated conditions prevailed in areas dominated by dehydration reactions. High $a \mathrm{H}_{2} \mathrm{O}$ values further support this conclusion. Fluid-saturated conditions in quartz- absent rocks prevail immediately above the melt-in isograd. Total volatile contents and $a \mathrm{H}_{2} \mathrm{O}$ decrease up-grade, consistent with the notion of $a \mathrm{H}_{2} \mathrm{O}$ being reduced as melting proceeds once the free $\mathrm{H}_{2} \mathrm{O}$ fluid is exhausted. The study was unable directly to demonstrate fluid-present $v$. fluid-absent conditions in quartz-present rocks of the Upper Spinel Zone. However, the presence of fluid-saturated quartz-absent rocks implies that $\mathrm{H}_{2} \mathrm{O}$ was available to flux melting in adjacent quartz-present layers and this may have reduced the $a \mathrm{H}_{2} \mathrm{O}$ in some quartz-absent rocks that may have not melted themselves. Low total volatile contents and $a \mathrm{H}_{2} \mathrm{O}$ values unequivocally demonstrate that fluid-absent conditions prevailed in the Sillimanite Zone. The lowest recorded $a \mathrm{H}_{2} \mathrm{O}$ values lie entirely within part of the section where fluidabsent melting reactions are thought to have dominated. Samples within $30 \mathrm{~m}$ of the igneous contact appear to be re-saturated, possibly via a magmatically derived fluid. The good agreement between indirectly determined melt $\mathrm{H}_{2} \mathrm{O}$ contents and experimentally determined melt $\mathrm{H}_{2} \mathrm{O}$ contents (Johannes \& Holtz, 1996) supports the conclusion that cordierite volatile contents can be used to assess the fluid conditions during metamorphism and partial melting, at least in a relatively simple thermal aureole, in which both prograde and retrograde metamorphism can be expected to have been rapid. Furthermore, the internally consistent cordierite volatile data and melt $\mathrm{H}_{2} \mathrm{O}$ data support the conclusion that the independent $P-T$ estimates applied in this study were valid. In situ FTIR spectroscopy provides a valuable, relatively cheap and rapid tool for determining $\mathrm{H}_{2} \mathrm{O}$ and $\mathrm{CO}_{2}$ contents in cordierite. 


\section{References}

Aines, R. D. \& Rossman, G. R., 1984. The high-temperature behaviour of water and carbon dioxide in cordierite and beryl. American Mineralogist, 69, 319-327.

Anderson, J. G. C., 1937. The Etive complex. Geological Society of London Quarterly Journal, 93, 487-533.

Armbruster, T. H. \& Bloss, F. D., 1982. Orientation and effects of channel $\mathrm{H}_{2} \mathrm{O}$ and $\mathrm{CO}_{2}$ in cordierite. American Mineralogist, 67, 248-291.

Carey, J. W., 1995. A thermodynamic formulation of hydrous cordierite. Contributions to Mineralogy and Petrology, 119, 155-165.

Carrington, D. P. \& Harley, S. L., 1996. Cordierite as a monitor of fluid and melt water contents in the lower crust: an experimental calibration. Geology, 24, 647-650.

Clemens, J. D. \& Droop, G. T. R., 1998. Fluid, P-T paths and the fates of anatectic melts in the Earth's crust. Lithos, 44, 21-36.

Cohen, J. P., Ross, F. K. \& Gibbs, G. V., 1977. An X-ray and neutron diffraction study of hydrous low cordierite. American Mineralogist, 62, 67-78.

Droop, G. T. R. \& Moazzen, M., 2007. Contact metamorphism and partial melting of Dalradian pelites and semipelites in the southern sector of the Etive aureole. Scottish Journal of Geology, 43, 1-25.

Droop, G. T. R. \& Treloar, P. J., 1981. Pressures of metamorphism in the thermal aureole of the Etive granite complex. Scottish Journal of Geology, 17, 85-102. 
Droop, G. T. R., Clemens, J. D. \& Dalrymple, D. J., 2003. Processes and conditions during contact anatexis, melt escape and restite formation: the Huntly Gabbro Complex, NE Scotland. Journal of Petrology, 60, 1-35.

Farrell, E. F. \& Newnham, R. E., 1967. Electronic and vibrational absorption spectra in cordierite. American Mineralogist, 52, 380-388.

Goldman, D. S., Rossman, G. R. \& Dollase, W. A., 1977. Channel constituents in cordierite. American Mineralogist, 62, 1144-1157.

Harley, S., 1994. Cordierite as a sensor of fluid and melt distribution in crustal metamorphism. Mineralogical Magazine, 58, 374-375, Goldschimt Conference.

Harley, S. \& Carrington, D. P., 2001. The distribution of $\mathrm{H}_{2} \mathrm{O}$ between cordierite and granitic melt: $\mathrm{H}_{2} \mathrm{O}$ incorporation in cordierite and its application to high-grade metamorphism and crustal anatexis. Journal of Petrology, 42, 1595-1620.

Harley, S., Thompson, P., Henson, B. J. \& Buick, I. S., 2002. Cordierite as a sensor of fluid conditions in high-grade metamorphism and crustal anatexis. Journal of Metamorphic Geology, 20, 71-86.

Holland, T. J. B., 1979. High water activities in the generation of high pressure kyanite eclogites of Tauern Window, Austria. Journal of Geology, 87, 1-28.

Holtz, F. \& Johannes, W., 1994. Maximum and minimum water contents of granitic melts: implications for chemical and physical properties of ascending magams. Lithos, 32, 149-159.

Johannes, W. \& Holtz, F., 1996. Petrogenesis and Experimental Petrology of Granitic Rocks. Springer Verlag, Berlin 
Johannes, W. \& Schreyer, W., 1981. Experimental introduction of $\mathrm{CO}_{2}$ and $\mathrm{H}_{2} \mathrm{O}$ into $\mathrm{Mg}$ cordierite. American Journal of Science, 281, 299-317.

Johnson, T. E., Hudson, N. F. C. \& Droop, G. T. R., 2001. Partial melting in the Inzie Head gneisses: the role of water and a petrogenetic grid in KFMASH applicable to anatectic pelitic migmatites. Journal of Metamorphic Geology, 19, 99-118.

Kalt, A., 2000. Cordierite channel volatiles as evidence for dehydration melting: an example from high-temperature metapelites of the Bayerische Wald (Variscan belt, Germany). European Journal of Mineralogy, 12, 987-998.

Kerrick, D. M., 1974. Review of mixed-volatile $\left(\mathrm{H}_{2} \mathrm{O}-\mathrm{CO}_{2}\right)$ equilibria. American Mineralogist, 59, 729-762.

Kolesov, B. A. \& Geiger, C. A., 2000. Cordierite II: The role of $\mathrm{CO}_{2}$ and $\mathrm{H}_{2} \mathrm{O}$. American Mineralogist, 85, 1265-1274.

Kretz, R., 1983. Symbols for rock forming minerals. American Mineralogist, 68, 148156.

Kurepin, V. A., 1985. $\mathrm{H}_{2} \mathrm{O}$ and $\mathrm{CO}_{2}$ contents of cordierite as an indicator of thermodynamic conditions of formation. Geochemistry International, 22, 148-156.

Mirwald, P. W. \& Schreyer, W., 1977. Die stabile and metastabile Abbaureaktion von Mg-cordierite in Talk, Disthen und quartz und ihre Abhangigkeit von Gleichgewichtswassergehalt des cordierites. Fortschritte der Mineralogie, 55, 97-99.

Mirwald, P. W., Maresch, W. V. \& Schreyer, W., 1979. Der Wassergehalt von Mgcordierite zwischen $500^{\circ}$ und $800^{\circ} \mathrm{C}$ sowie 0.5 und 11 kbar. Fortschritte der Mineralogie, 57, beiheft 1, 101-102. 
Moazzen, M., 1999. Contact Metamorphic Processes in the Etive Aureole, Scotland. PhD Thesis, University of Manchester, Manchester

Moazzen, M. \& Droop, G. T. R., 2005. Application of mineral thermometers and barometers to granitoid igneous rocks: the Etive Complex, W Scotland. Mineralogy and Petrology, 83, 27-53.

Moazzen, M., Droop, G. T. R. \& Harte, B., 2001. Abrupt transition in $\mathrm{H}_{2} \mathrm{O}$ activity in the melt-present zone of a thermal aureole: evidence from $\mathrm{H}_{2} \mathrm{O}$ contents of cordierites. Geology, 29, 311-314.

Newton, R. C. \& Wood, B. J., 1979. Thermodynamics of water in cordierite and some petrologic consequences of cordierite as a hydrous system. Contributions to Mineralogy and Petrology, 68, 391-405.

Pattison, D. R. M., 1991. Infiltration-driven dehydration and anatexis in granulite facies metagabbro, Grenville Province, Ontario, Canada. Journal of Metamorphic Geology, 9, $315-332$.

Pattison, D. R. M. \& Harte, B., 1985. A petrogenetic grid for pelites in the Ballachulish igneous complex and aureole. Journal of the Geological Society of London, 142, 7-28.

Pattison, D. R. M. \& Harte, B., 1988. Evolution of structurally contrasting anatectic migmatites in the 3 kbar Ballachulish aureole, Scotland. Journal of Metamorphic Geology, 6, 475-494.

Pouchou, J. L. \& Pichoir, F., 1991. Quantitative analysis of homogeneous or stratified microvolumes applying the model "PAP'. In: Electron Probe Quantitation (eds Heinrich, K. F. J. \& Newbury, D. E.), pp. 31-75. Plenum Press, New York. 
Powell, R., 1983. Fluids and melting in upper amphibolite facies conditions. Geological Society of London Journal, 140, 629-634.

Rigby, M. J., 2006. Cordierite as a Monitor of Volatile Content during Metamorphism and Partial Melting. PhD Thesis, University of Manchester, Manchester

Rutter, E. H. \& Brodie, K. H., 1985. The permeation of water into hydrating shear zones. In: Metamorphic Reactions, Kinectics, Textures and Deformation (eds Thompson, A. B. \& Rubie, D. C.), pp. 242-250. Springer, New York

Sawyer, E. W., 1999. Criteria for the recognition of partial melting. Physcial Chemistry of the Earth, 24, 269-279.

Stevens, G., Clemens, J. D. \& Droop, G. T. R., 1995. Hydrous cordierite in granulite and crustal magma production. Geology, 23, 925-928.

Thompson, A. B., 1982. Dehydration melting of pelitic rocks and the generation of $\mathrm{H}_{2} \mathrm{O}-$ undersaturated granitic liquids. American Journal of Science, 124, 1567-1595.

Thompson, P., Harley, S. L. \& Carrington, D. P., 2001. The distribution of $\mathrm{H}_{2} \mathrm{O}-\mathrm{CO}_{2}$ between cordierite and granitic melt under fluid-saturated conditions at $5 \mathrm{kbar}$ and $900^{\circ} \mathrm{C}$. Contribution to Mineralogy and Petrology, 142, 107-118.

Vernon, R. H., 1979. Formation of late sillimanite by hydrogen metasomatism (baseleaching) in some high-grade gneisses. Lithos, 12, 143-152.

Vernon, R. H. \& Collins, W. J., 1988. Igneous microstructures in migmatites. Geology, 16, 1126-1129. 
Vry, J. K., Brown, P. E. \& Valley, J. W., 1990. Cordierite volatile content and the role of $\mathrm{CO}_{2}$ in high-grade metamorphism. American Mineralogist, 75, 71-88.

Waters, D. J., 1988. Partial melting and the formation of granulite facies assemblages in Namaqualand, South Africa. Journal of Metamorphic Geology, 6, 387-404.

Wood, D. L. \& Nassau, K., 1967. Infrared spectra of foreign molecules in beryl. Journal of Chemical Physics, 22, 2220-2228. 


\section{Appendix}

Grid references and peak-metamorphic mineral assemblages of the samples studied.

\begin{tabular}{|c|c|c|c|c|c|c|c|c|c|c|c|c|c|c|c|}
\hline Sample no. & Zone & $\begin{array}{c}\text { Distance from } \\
\text { contact (m) }\end{array}$ & Grid reference & Crd & Qtz & Ms & Bt & Kfs & Pl & And & Sil & Crn & Spl & Grt & Opx \\
\hline MM181 & III & 970 & NN 12492787 & $\mathrm{x}$ & $\mathrm{x}$ & & $\mathrm{x}$ & $\mathrm{x}$ & $\mathrm{x}$ & $\mathrm{x}$ & & & & & \\
\hline MD1 & III & 950 & NN 11392618 & $\mathrm{x}$ & $\mathrm{x}$ & $\mathrm{x}$ & $\mathrm{x}$ & $\mathrm{x}$ & & $\mathrm{x}$ & & & & & \\
\hline MM129 & IV & 800 & NN 11572755 & $\mathrm{x}$ & & & $\mathrm{x}$ & $\mathrm{x}$ & $\mathrm{x}$ & $\mathrm{x}$ & & $\mathrm{x}$ & & & \\
\hline MM184B & IV & 620 & NN 12312818 & $\mathrm{x}$ & & & $\mathrm{x}$ & $\mathrm{x}$ & $\mathrm{x}$ & $\mathrm{x}$ & & $\mathrm{x}$ & & & \\
\hline MM151 & V & 680 & NN 11882786 & $\mathrm{x}$ & & & $\mathrm{x}$ & $\mathrm{x}$ & $\mathrm{x}$ & $\mathrm{x}$ & & & $\mathrm{x}$ & & \\
\hline MM131 & V & 640 & NN 11342763 & $\mathrm{x}$ & & & $\mathrm{x}$ & $\mathrm{x}$ & & $\mathrm{x}$ & & $\mathrm{x}$ & & & \\
\hline MM185B & $\mathrm{V}$ & 490 & NN 12192825 & $\mathrm{x}$ & & & $\mathrm{x}$ & $\mathrm{x}$ & $\mathrm{x}$ & $\mathrm{x}$ & & $\mathrm{x}$ & & & \\
\hline MM176 & V & 470 & NN 12642859 & $\mathrm{x}$ & $\mathrm{x}$ & & $\mathrm{x}$ & $\mathrm{x}$ & $\mathrm{x}$ & $\mathrm{x}$ & & & & & \\
\hline MM133 & $\mathrm{Vm}$ & 450 & NN 11442787 & $\mathrm{x}$ & $\mathrm{x}$ & & $\mathrm{x}$ & $\mathrm{x}$ & $\mathrm{x}$ & $\mathrm{x}$ & & & & & \\
\hline MM186B & $\mathrm{Vm}$ & 430 & NN 12092826 & $\mathrm{x}$ & $\mathrm{x}$ & & $\mathrm{x}$ & $\mathrm{x}$ & $\mathrm{x}$ & $\mathrm{x}$ & & & & & \\
\hline MM187 & $\mathrm{Vm}$ & 390 & NN 12052830 & $\mathrm{x}$ & & & $\mathrm{x}$ & $\mathrm{x}$ & $\mathrm{x}$ & $\mathrm{x}$ & & $\mathrm{x}$ & & & \\
\hline MM135A & $\mathrm{Vm}$ & 350 & NN 11372795 & $\mathrm{x}$ & & & $\mathrm{x}$ & $\mathrm{x}$ & $\mathrm{x}$ & & & $\mathrm{x}$ & $\mathrm{x}$ & & \\
\hline MM188C & $\mathrm{Vm}$ & 330 & NN 11992832 & $\mathrm{x}$ & & & $\mathrm{x}$ & $\mathrm{x}$ & $\mathrm{x}$ & $\mathrm{x}$ & & $\mathrm{x}$ & & & \\
\hline MM174B & $\mathrm{Vm}$ & 300 & NN 12542876 & $\mathrm{x}$ & & & $\mathrm{x}$ & $\mathrm{x}$ & $\mathrm{x}$ & $\mathrm{x}$ & & & $\mathrm{x}$ & & \\
\hline MD12 & $\mathrm{Vm}$ & 240 & NN 12022843 & $\mathrm{x}$ & & & $\mathrm{x}$ & $\mathrm{x}$ & $\mathrm{x}$ & $\mathrm{x}$ & & $\mathrm{x}$ & $\mathrm{x}$ & & \\
\hline MM171 & $\mathrm{Vm}$ & 180 & NN 12412878 & $\mathrm{x}$ & & & $\mathrm{x}$ & $\mathrm{x}$ & $\mathrm{x}$ & $\mathrm{x}$ & & $\mathrm{x}$ & $\mathrm{x}$ & & \\
\hline MM144 & $\mathrm{Vm}$ & 140 & NN 11612834 & $\mathrm{x}$ & & & & & $\mathrm{x}$ & $\mathrm{x}$ & $\mathrm{x}$ & $\mathrm{x}$ & & & \\
\hline MM195A & $\mathrm{Vm}$ & 140 & NN 12282874 & $\mathrm{x}$ & $\mathrm{x}$ & & $\mathrm{x}$ & $\mathrm{x}$ & $\mathrm{x}$ & & & & & & \\
\hline
\end{tabular}




\begin{tabular}{|c|c|c|c|c|c|c|c|c|c|c|c|c|c|c|}
\hline MM169 & $\mathrm{Vm}$ & 135 & NN 12322875 & $\mathrm{x}$ & & $\mathrm{x}$ & $\mathrm{x}$ & $\mathrm{x}$ & $\mathrm{x}$ & $\mathrm{x}$ & & $\mathrm{x}$ & & \\
\hline MM166A & VI m & 130 & NN 12512896 & $\mathrm{x}$ & $\mathrm{x}$ & $\mathrm{x}$ & $\mathrm{x}$ & $\mathrm{x}$ & & & & & $\mathrm{x}$ & \\
\hline MM164 & VI m & 120 & NN 12572905 & $\mathrm{x}$ & & $\mathrm{x}$ & $\mathrm{x}$ & $\mathrm{x}$ & & & & $\mathrm{x}$ & & \\
\hline MM143 & VI m & 100 & NN 11572835 & $\mathrm{x}$ & & $\mathrm{x}$ & $\mathrm{x}$ & $\mathrm{x}$ & $\mathrm{X}$ & $\mathrm{x}$ & $\mathrm{x}$ & $\mathrm{x}$ & & \\
\hline MM194B & VI m & 110 & NN 12112864 & $\mathrm{x}$ & & & $\mathrm{x}$ & $\mathrm{x}$ & $\mathrm{x}$ & $\mathrm{x}$ & $\mathrm{x}$ & $\mathrm{x}$ & & \\
\hline MM166E & VI m & 90 & NN 12452895 & $\mathrm{x}$ & & $\mathrm{x}$ & $\mathrm{x}$ & $\mathrm{x}$ & $\mathrm{x}$ & $\mathrm{x}$ & $\mathrm{x}$ & $\mathrm{x}$ & & \\
\hline MM166F & VI m & 90 & NN 12452895 & $\mathrm{x}$ & & $\mathrm{x}$ & $\mathrm{x}$ & $\mathrm{x}$ & $\mathrm{x}$ & $\mathrm{x}$ & & $\mathrm{x}$ & & \\
\hline MM166C & VI m & 90 & NN 12452895 & $\mathrm{x}$ & & $\mathrm{x}$ & $\mathrm{x}$ & $\mathrm{x}$ & $\mathrm{x}$ & $\mathrm{x}$ & $\mathrm{x}$ & $\mathrm{x}$ & & \\
\hline MM166D & VI m & 90 & NN 12452895 & $\mathrm{x}$ & & $\mathrm{x}$ & $\mathrm{x}$ & $\mathrm{x}$ & $\mathrm{x}$ & $\mathrm{x}$ & $\mathrm{x}$ & $\mathrm{x}$ & & \\
\hline MD19 & VI m & 70 & NN 12222876 & $\mathrm{x}$ & $\mathrm{x}$ & $\mathrm{x}$ & $\mathrm{x}$ & $\mathrm{x}$ & & & & & & $\mathrm{x}$ \\
\hline MD18 & VI m & 30 & NN 12162877 & $\mathrm{x}$ & $\mathrm{x}$ & $\mathrm{x}$ & $\mathrm{x}$ & $\mathrm{x}$ & & & & & & $\mathrm{x}$ \\
\hline M198C & VI m & 15 & NN 12492911 & $\mathrm{x}$ & $\mathrm{x}$ & $\mathrm{x}$ & & $\mathrm{x}$ & & & & & & $\mathrm{x}$ \\
\hline MM197A & VI m & 15 & NN 12412900 & $\mathrm{x}$ & & $\mathrm{x}$ & $\mathrm{x}$ & $\mathrm{x}$ & $\mathrm{x}$ & $\mathrm{x}$ & $\mathrm{x}$ & $\mathrm{x}$ & & \\
\hline MM193Y & VI m & 3 & NN 11912862 & $\mathrm{x}$ & & $\mathrm{x}$ & $\mathrm{x}$ & $\mathrm{x}$ & & $\mathrm{x}$ & $\mathrm{x}$ & $\mathrm{x}$ & & \\
\hline MD9A & VI mx & 0.01 & NN 11202830 & $\mathrm{x}$ & & & $\mathrm{x}$ & $\mathrm{x}$ & $\mathrm{x}$ & $\mathrm{x}$ & $\mathrm{x}$ & $\mathrm{x}$ & & \\
\hline MD9B & VI mx & 0.01 & NN 11202831 & $\mathrm{x}$ & & & $\mathrm{x}$ & $\mathrm{x}$ & $\mathrm{x}$ & $\mathrm{x}$ & $\mathrm{x}$ & $\mathrm{x}$ & & \\
\hline
\end{tabular}

III, And + Kfs zone; IV, Corundum Zone; V, Spinel Zone; VI, Sillimanite Zone; m, foliation-parallel leucosomes (in situ melt) present; x, xenolith in Quarry Diorite. Mineral abbreviations after Kretz (1983). 
Fig. 1. (a) Location of the Etive Complex in Scotland. Coordinates: latitude and longitude. (b) The Etive Igneous Complex (adapted from Anderson, 1937): the Outer Starav, Inner Starav and Meall Odhar intrusions are granites; the Cruachan intrusion is granodiorite. Coordinates: UK National Grid sheet NN. (c) The southern sector of the Etive thermal aureole in the vicinity of Lochawe: metamorphic zones and isograds from Droop \& Moazzen (2007); formation boundaries from British Geological Survey (Scotland) Sheet 45(E)/Dalmally/. Coordinates: UK National Grid sheet NN.
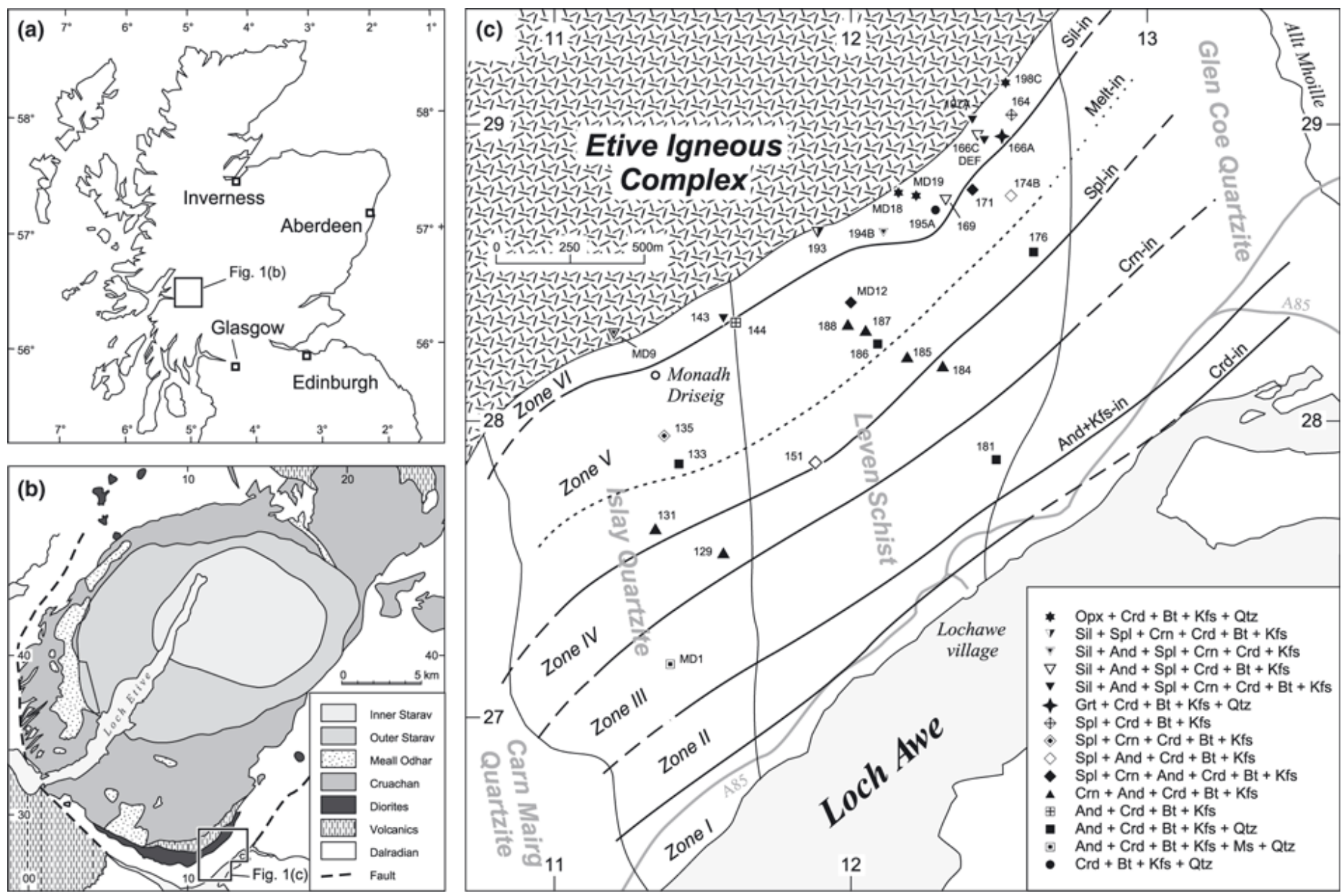
Fig. 2. A representative FTIR spectrum for cordierite.

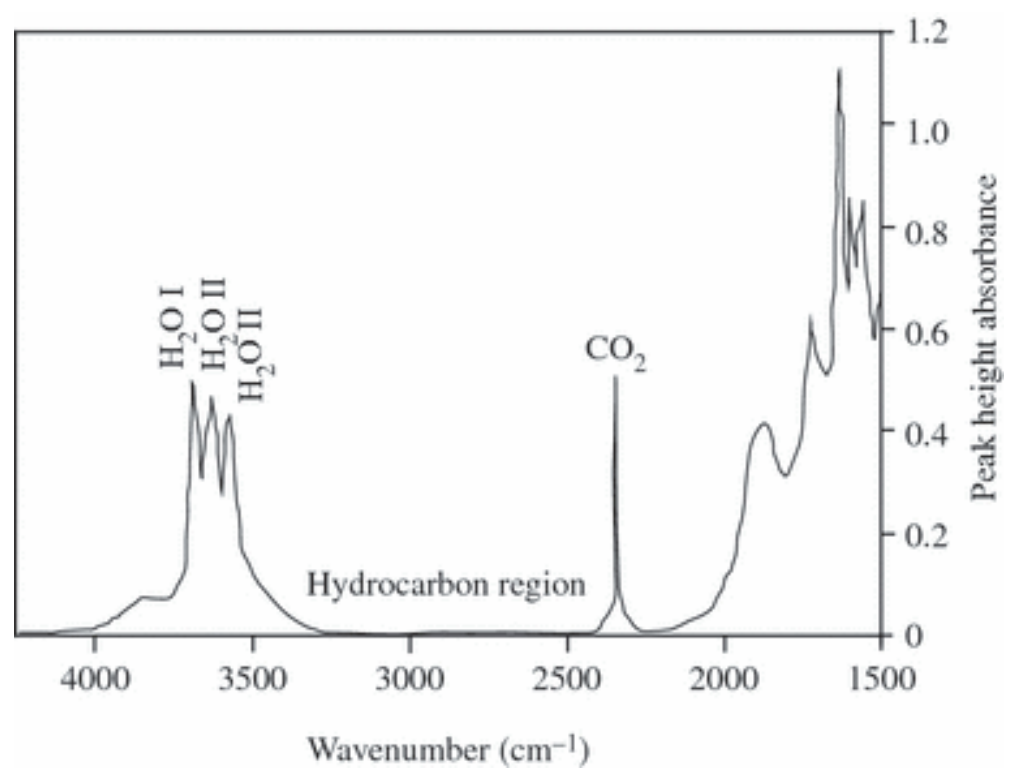

Fig. 3. Zoning profile for a typical cordierite (obtained by FTIR). Diamonds, total water, triangles indicate type $\mathrm{I}_{2} \mathrm{O}$; squares, type $\mathrm{II}_{2} \mathrm{O}$. There is little intra-grain variation.

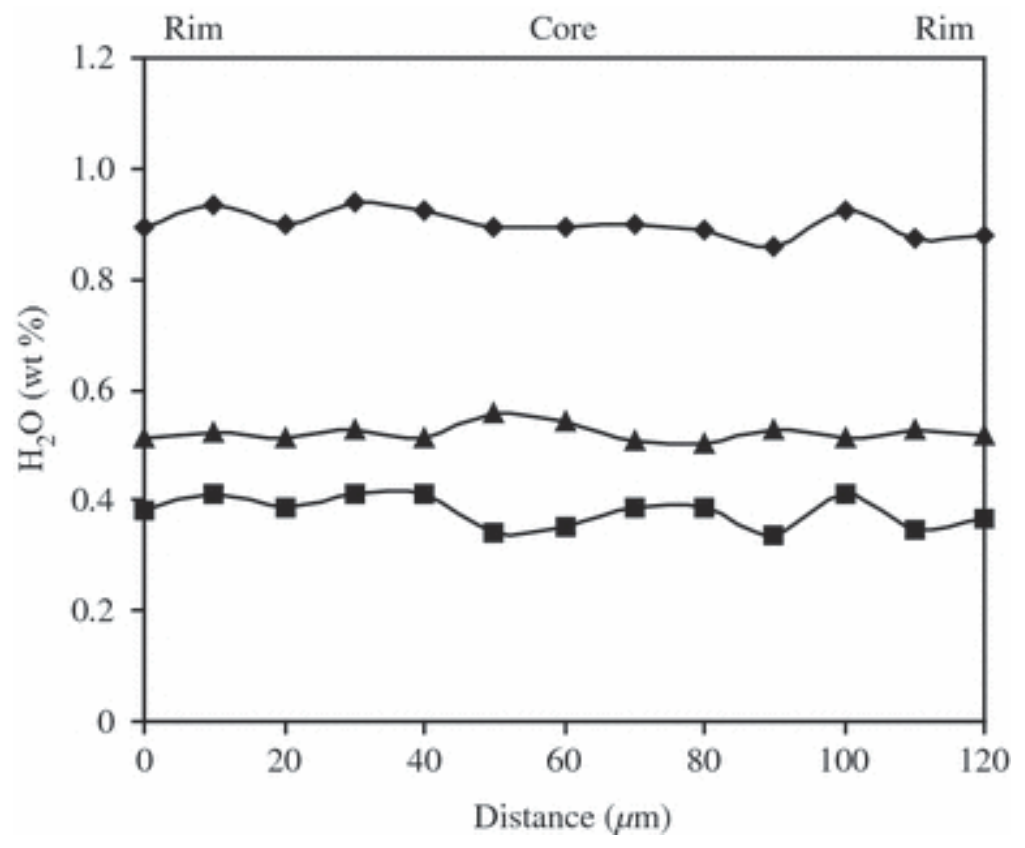


Fig. 4. Zoning profile for cordierite in sample MM171 (obtained by FTIR). Triangles, total water; diamonds, type- $\mathrm{H}_{2} \mathrm{O}$; squares, type- $\mathrm{II} \mathrm{H}_{2} \mathrm{O}$. The relative increase in total $\mathrm{H}_{2} \mathrm{O}$ is correlated with the increase in type $\mathrm{II}_{2} \mathrm{O}$ across the grain.

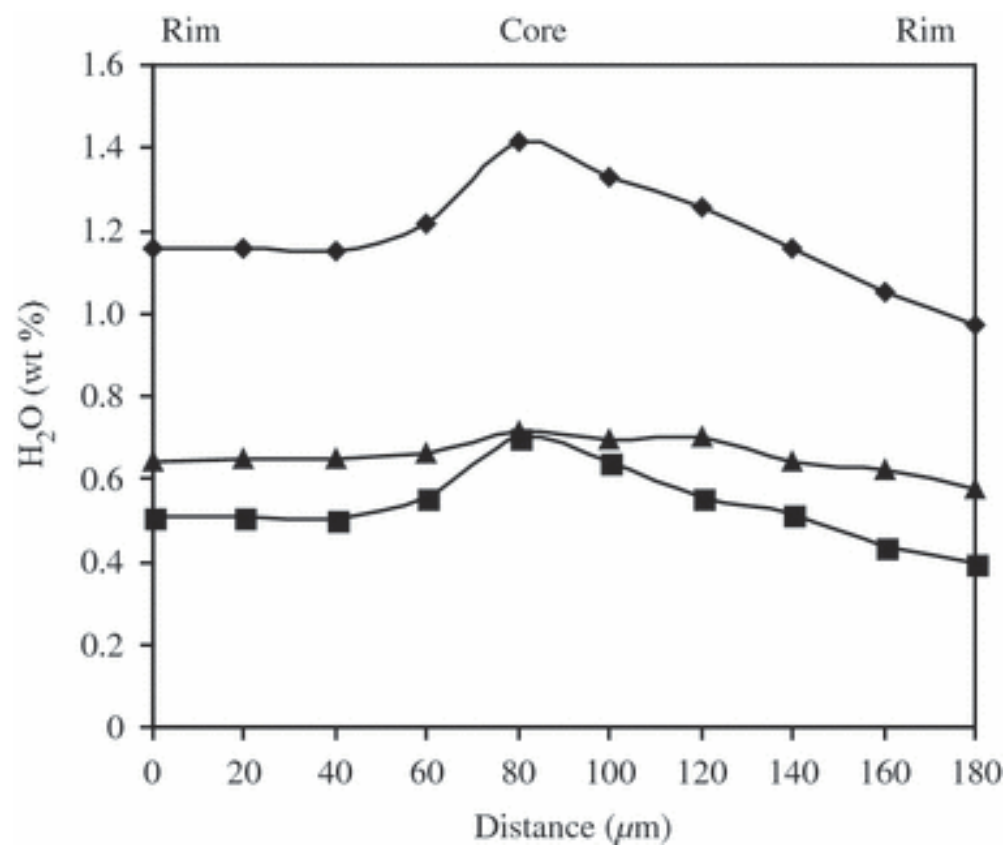

Fig. 5. Variation in total $\mathrm{H}_{2} \mathrm{O}$ wt $\%$ in cordierite (determined by FTIR) across the Etive thermal aureole. The locations of the isograds are shown for comparison. There is marked decrease in the $\mathrm{H}_{2} \mathrm{O}$ wt\% beyond the melt-in isograd. The lowest $\mathrm{H}_{2} \mathrm{O}$ contents occur upgrade of the sillimanite isograd, approximately $70 \mathrm{~m}$ from the igneous contact.

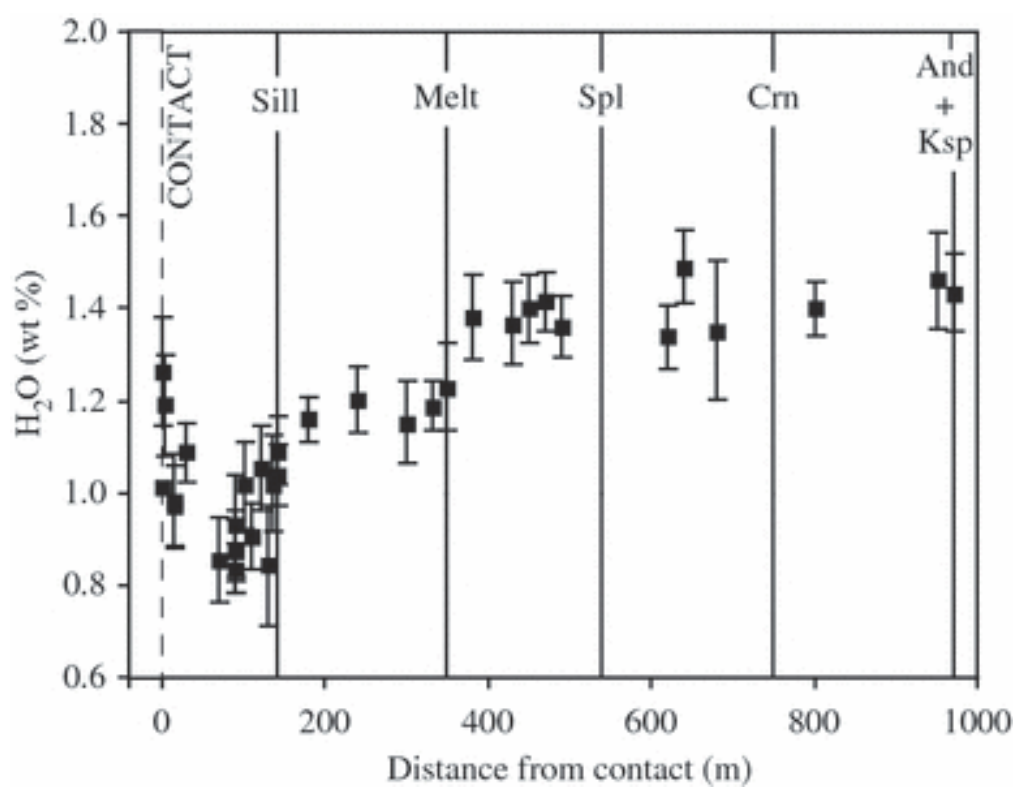


Fig. 6. Variation in the ratio of type I to type II $\mathrm{H}_{2} \mathrm{O}$ in cordierite across the Etive thermal aureole.

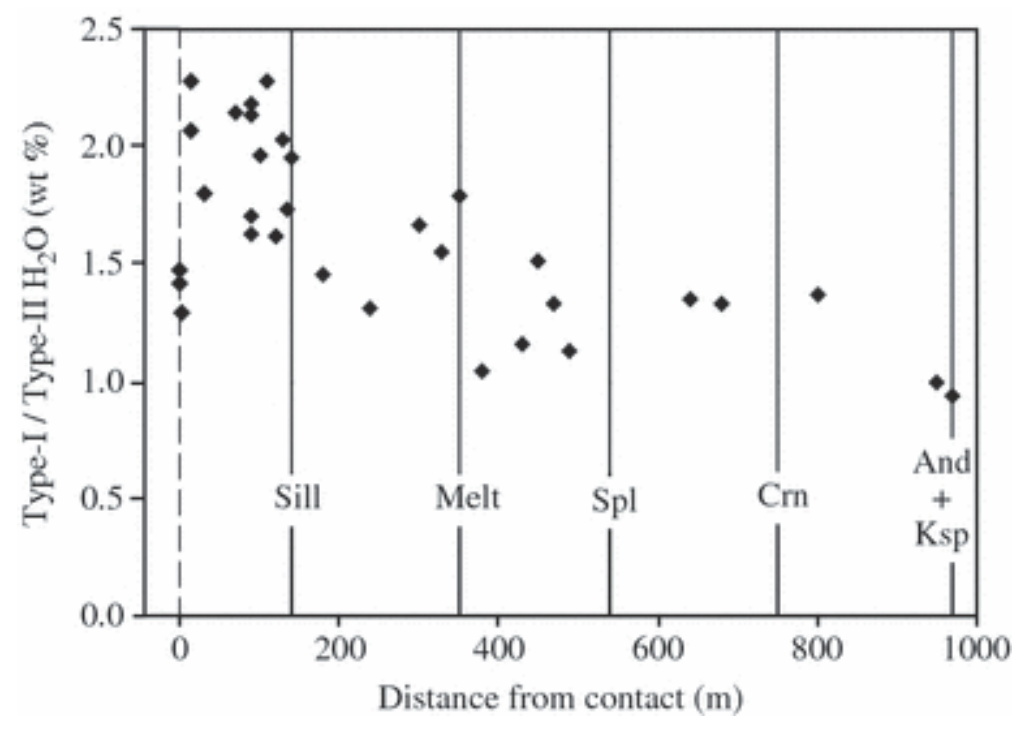

Fig. 7. Total channel cation abundances $v$. type $\mathrm{II}_{2} \mathrm{O}$ abundance. The straight line illustrates the predicted 2:1 ratio. The data show a reasonably good fit but deviate at high molar values of type $\mathrm{II} \mathrm{H}_{2} \mathrm{O}$.

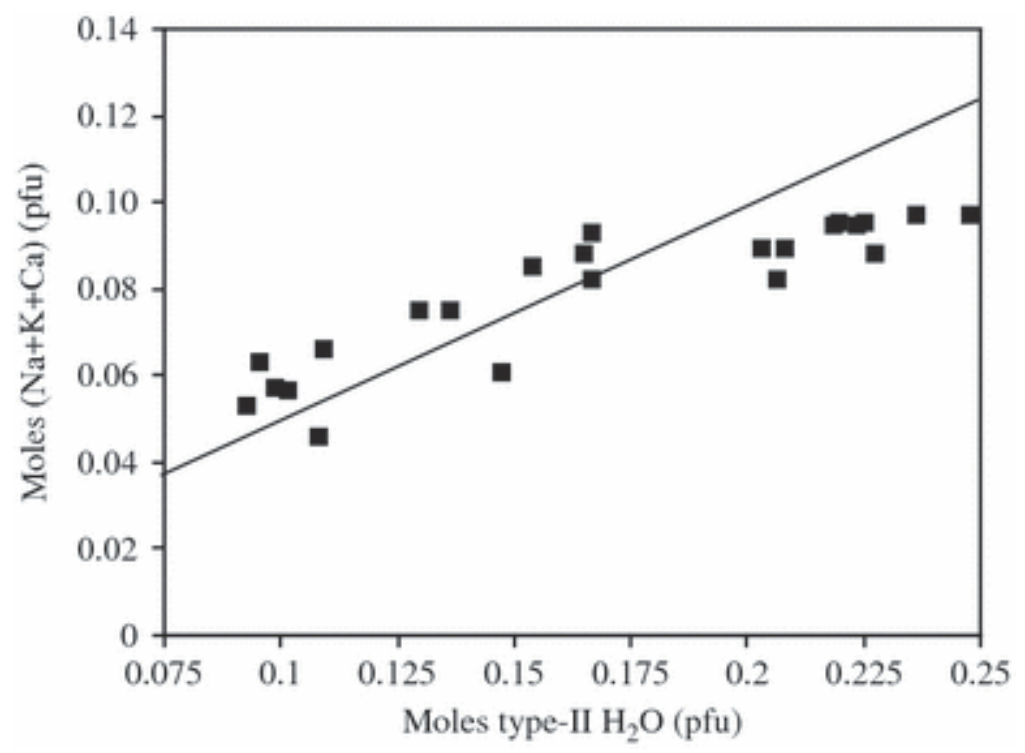


Fig. 8. Variation in type $\mathrm{II} \mathrm{H}_{2} \mathrm{O}$ (squares) and total channel cations $(\mathrm{K}+\mathrm{Ca}+\mathrm{Na})$ (diamonds) across the thermal aureole. The decrease in total channel cation content is

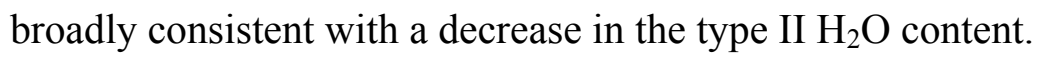

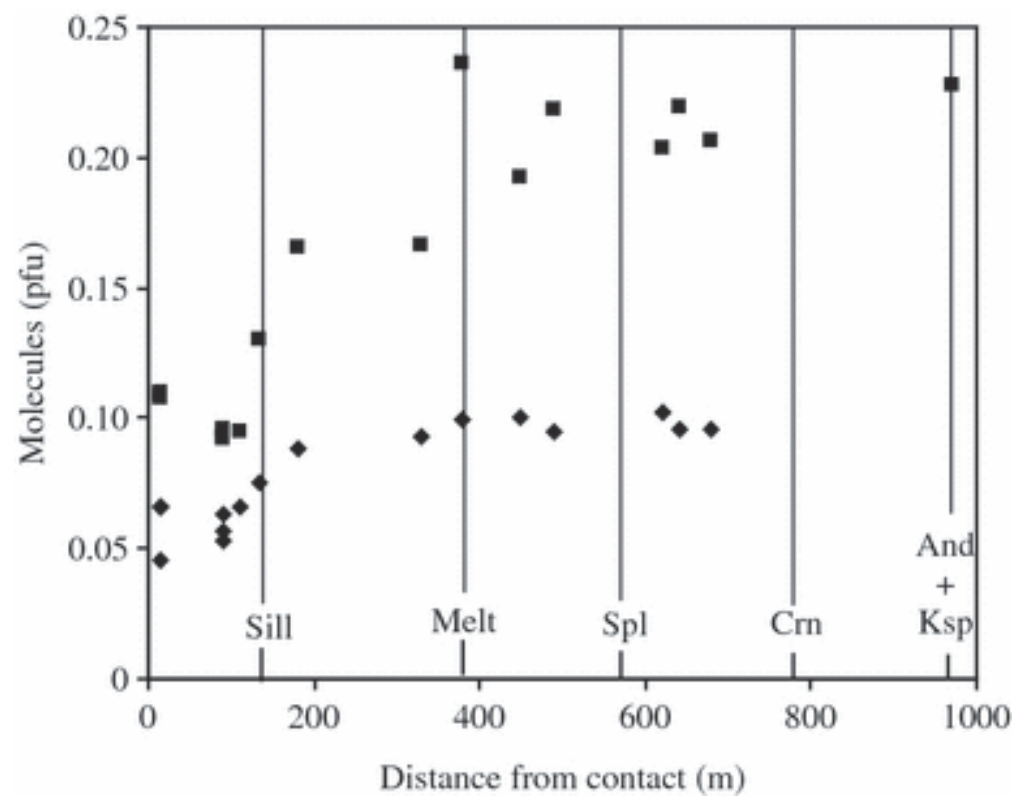

Fig. 9. Variation in $\mathrm{wt} \% \mathrm{CO}_{2}$ across the Etive thermal aureole. $\mathrm{CO}_{2}$ levels are generally low and uniformly distributed. Samples immediately adjacent to the igneous contact show considerably higher values.

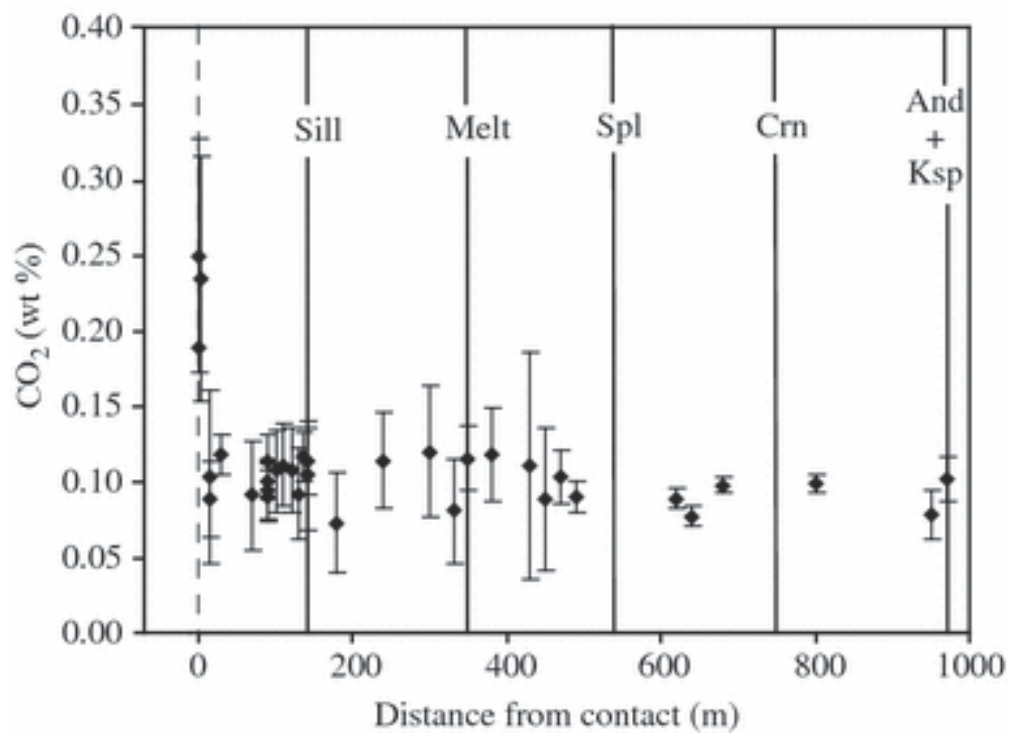


Fig. 10. A comparison of the measured $\mathrm{H}_{2} \mathrm{O}$ wt $\%$ contents of cordierite using SIMS (Moazzen et al., 2001) and FTIR (this study).

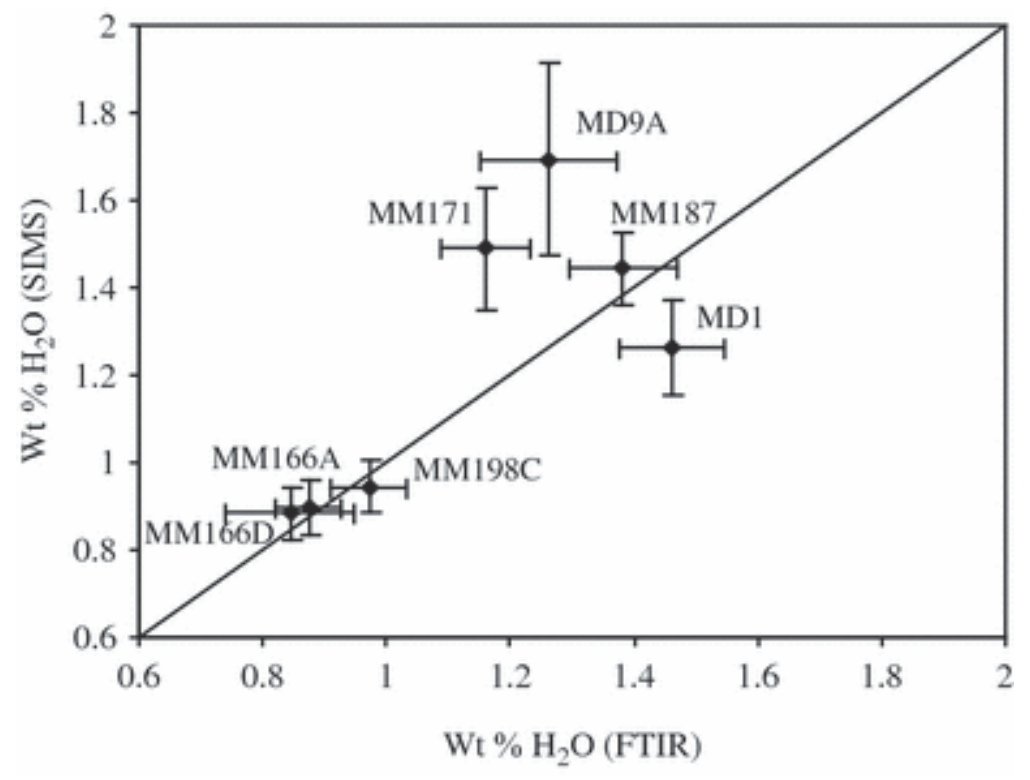

Fig. 11. A comparison of measured values of $n$ to the modelled $2.2 \mathrm{kbar} \mathrm{H}_{2} \mathrm{O}$-only saturation surface. The dashed line represents the $\mathrm{H}_{2} \mathrm{O}$-only saturation surface modelled using the thermodynamic data and methods of Harley \& Carrington (2001). Note the expanded $y$-axis scale. Samples prior to and just beyond the melt-in isograd (in Qtz-rich lithologies) are, within error, $\mathrm{H}_{2} \mathrm{O}$-saturated. At higher grades, beyond the onset of partial melting, and up to within $30 \mathrm{~m}$ of the igneous contact $\left(\sim 800^{\circ} \mathrm{C}\right)$ samples are predominantly $\mathrm{H}_{2} \mathrm{O}$-undersaturated. The solid lines mark the positions of the isograds.

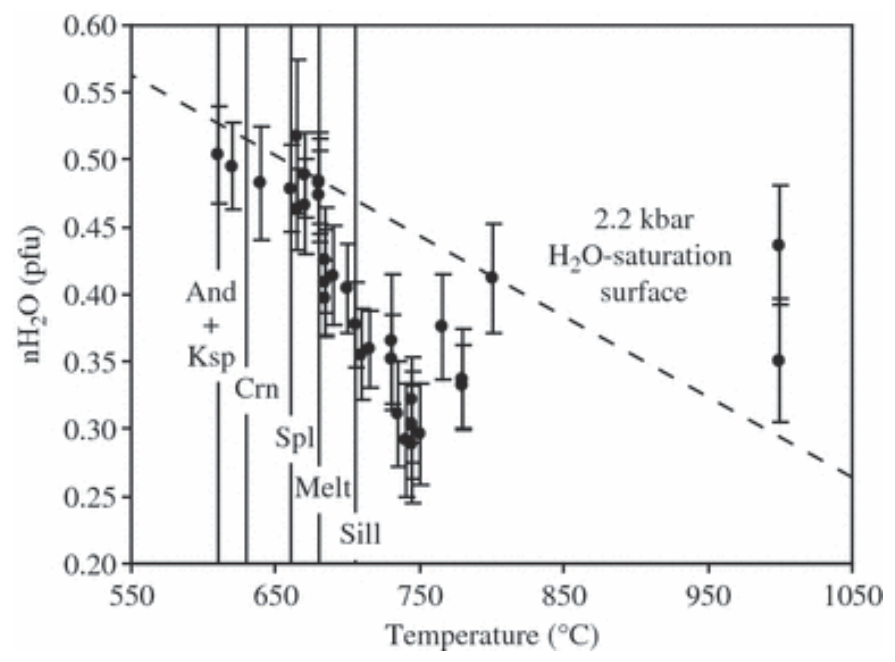


Fig. 12. A comparison of the mean total volatile content (molecules $n+m$ p.f.u.) of cordierite from the And $+\mathrm{Kfs}$ and Lower Spinel zones against modelled volatile saturation surfaces at $2.2 \mathrm{kbar}$ and various temperatures. Note the expanded $y$-axis scale. Saturation surfaces were modelled using the methods of Harley et al. (2002). The solid curves indicate the upper and lower volatile saturation limits constrained for And $+\mathrm{Kfs}$ and Lower Spinel Zone temperature estimates. Mean values for all samples fall within the limits represented by the total volatile saturation curves implying that fluid-present conditions prevailed.

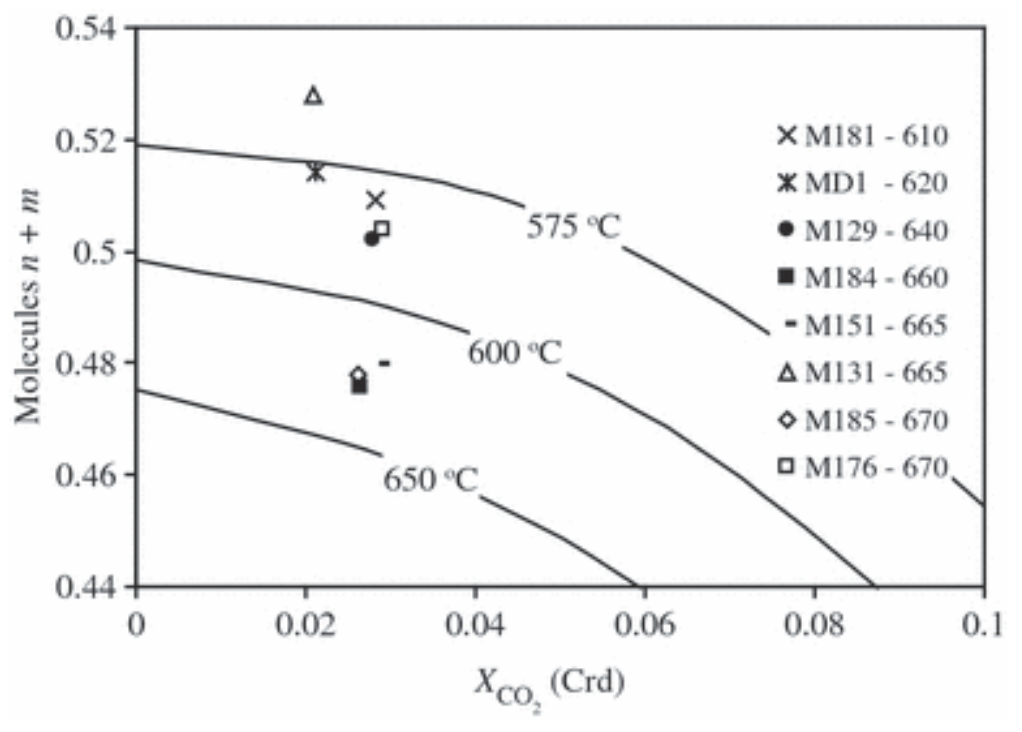


Fig. 13. A comparison of the mean total volatile content (molecules $n+m$ p.f.u.) of cordierite from the Upper Spinel Zones against modelled volatile saturation surfaces at $2.2 \mathrm{kbar}$ and various temperatures. Note the expanded $y$-axis scale. Saturation surfaces were modelled using the methods of Harley et al. (2002). The solid curves indicate volatile saturation limits. Including the total error, mean values for all samples, bar MM144, intersect the total volatile saturation curves at the temperature of interest, implying that fluid-present conditions prevailed.

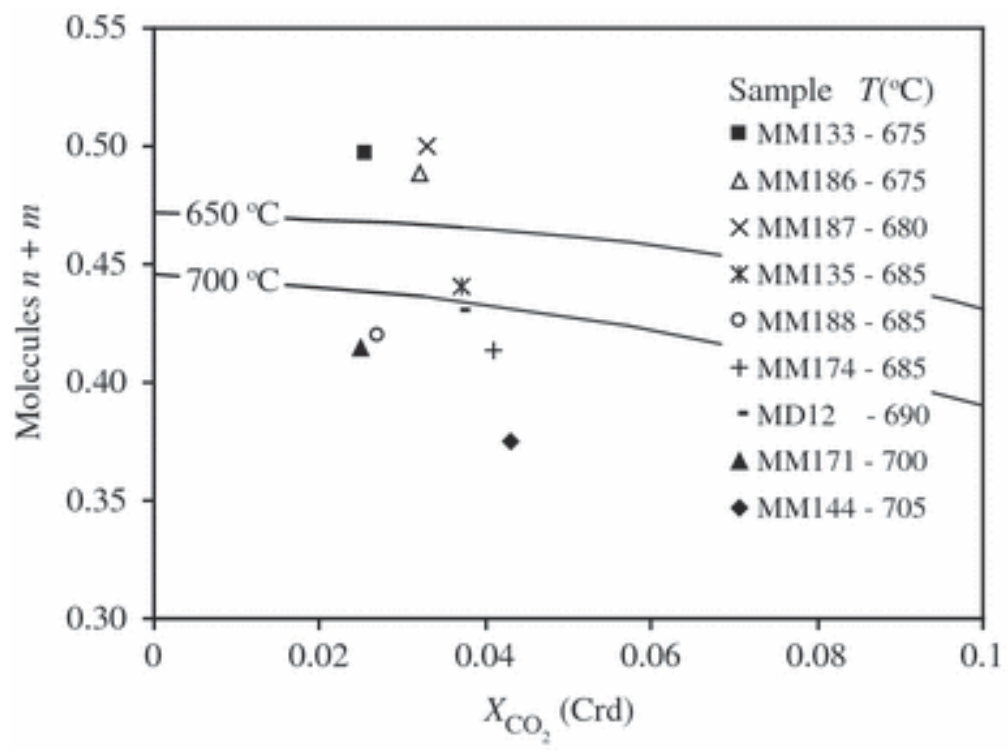


Fig. 14. Comparison of the total volatile content (molecules $n+m$ p.f.u.) of cordierite in the Sillimanite Zone against modelled volatile saturation surfaces at the $P-T$ of interest. Note the expanded $y$-axis scale. Mean values for samples that are not immediately adjacent to the igneous body plot well below the saturation curves at the temperatures of interest.

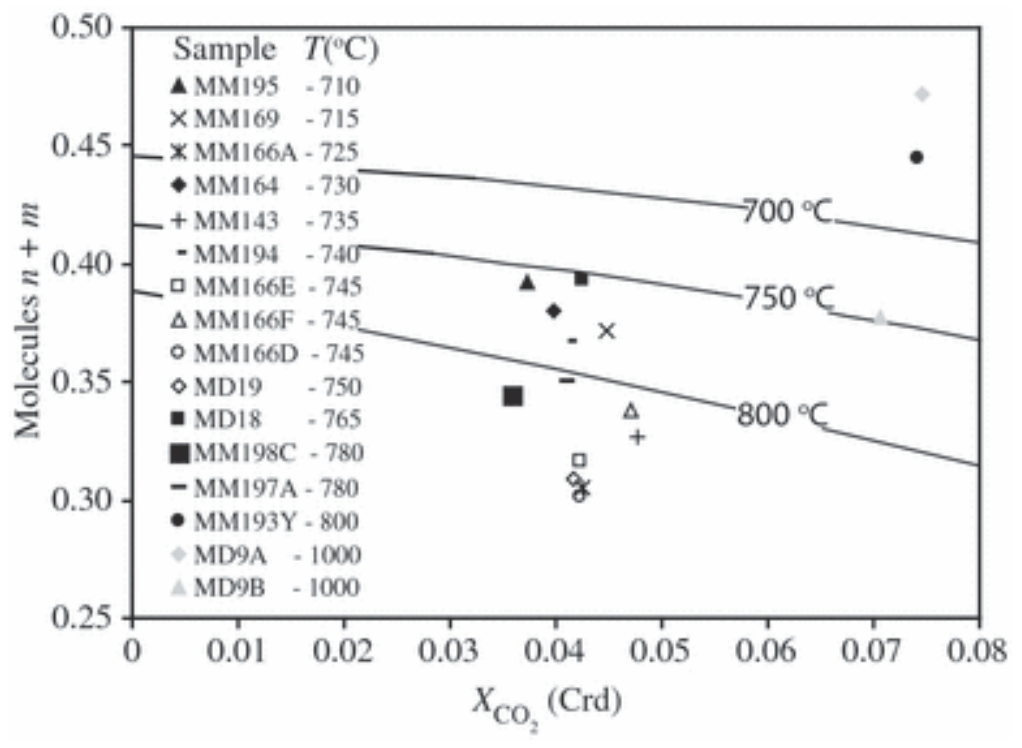


Fig. 15. Estimated $\mathrm{H}_{2} \mathrm{O}$ content of melts coexisting with cordierite-bearing samples at various temperatures across the inner aureole. Sillimanite Zone samples in the temperature range $715-750^{\circ} \mathrm{C}$ plot on, or at least very close to, the minimum solubility curve of Johannes \& Holtz (1996). Sillimanite Zone samples within $30 \mathrm{~m}$ of the intrusion (temperatures $>790{ }^{\circ} \mathrm{C}$ ) deviate from the minimum $\mathrm{H}_{2} \mathrm{O}$ curve and commonly plot above the maximum. Error bars include the uncertainty in temperature and the analytical population only.

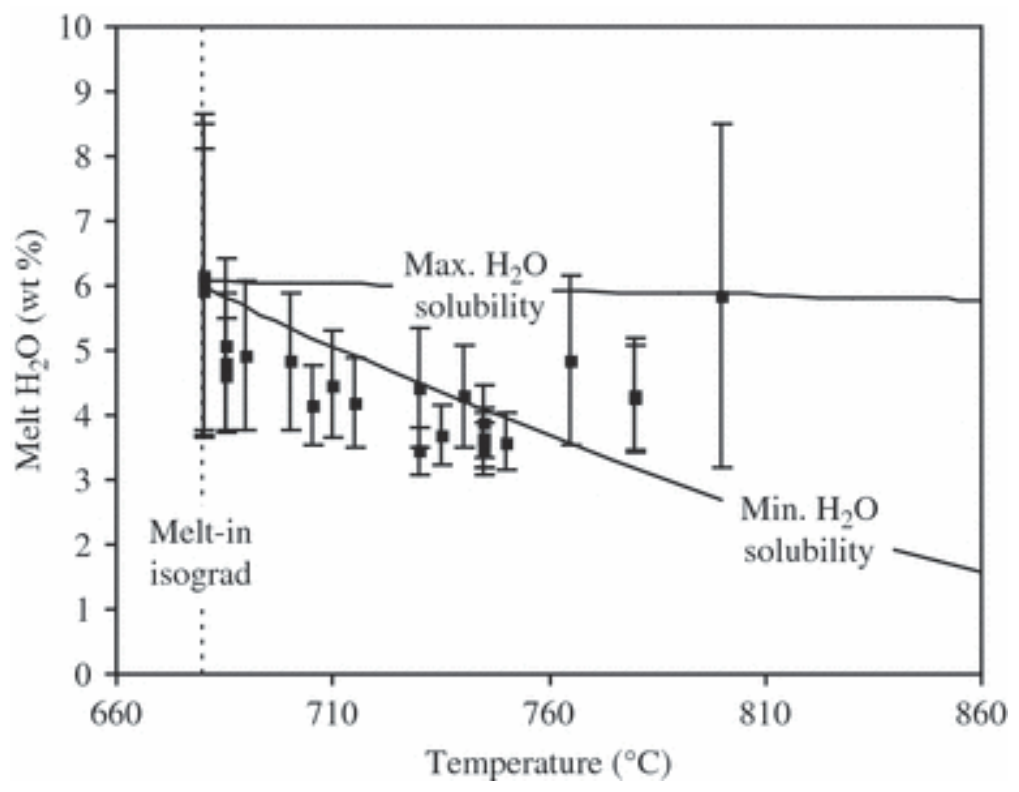


Fig. 16. Variation in $a \mathrm{H}_{2} \mathrm{O}$ across the Etive thermal aureole. There is marked decrease in $a \mathrm{H}_{2} \mathrm{O}$ beyond the onset of partial melting. The lowest recorded values lie entirely within part of the section where fluid-absent melting reactions are thought to have dominated. Error bars $(1 \sigma)$ include the uncertainty in temperature and the analytical population only.

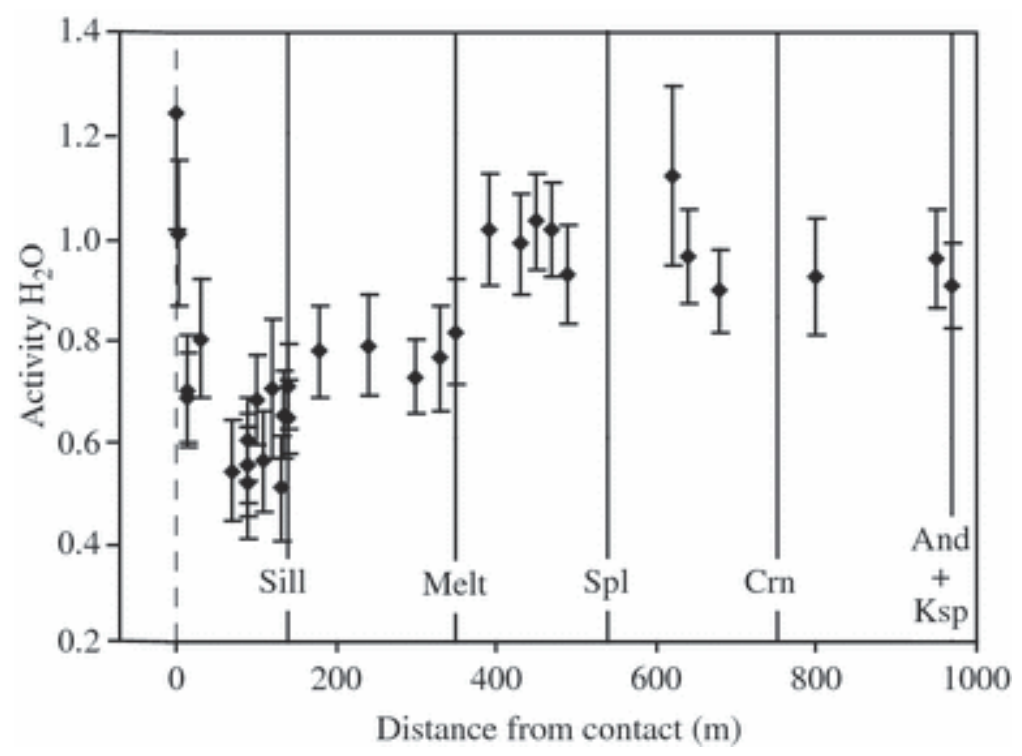

Fig. 17. Variation in total volatile content $(n+m)$ has a function of temperature. There is gradual decrease in total volatile contents up-temperature. The localized high-temperature increase is inferred to represent re-saturation immediately adjacent to the igneous contact.

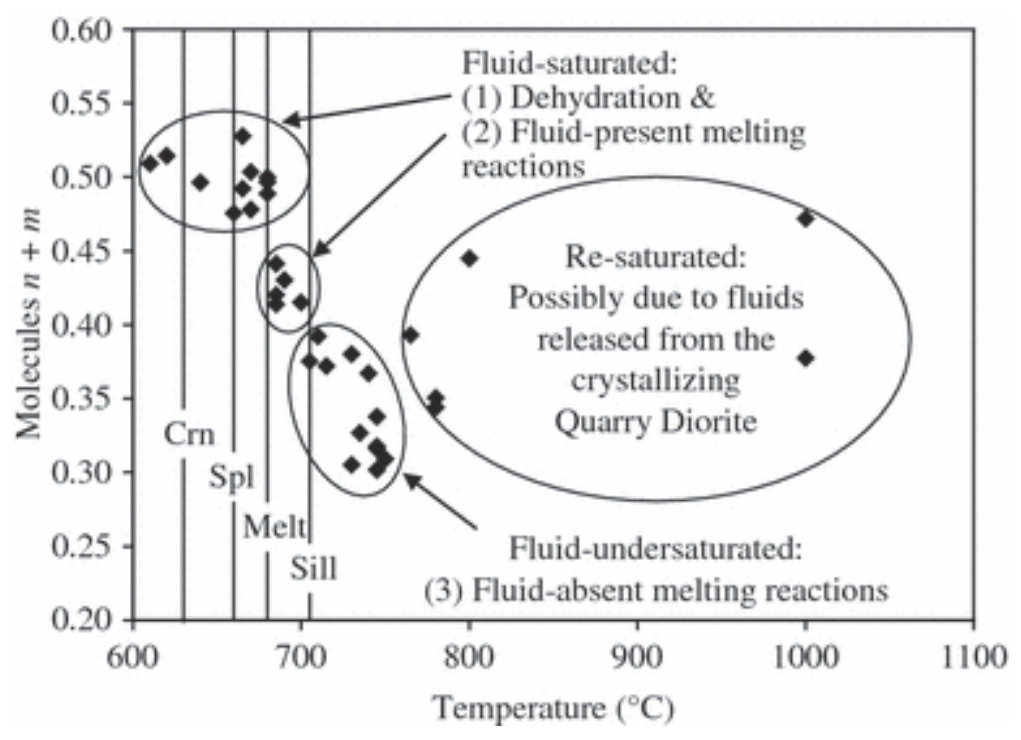


Table 1. Representative EPMA analyses of cordierite, calculated on the basis of 18 oxygen.

\begin{tabular}{|c|c|c|c|c|c|c|c|c|c|c|c|c|c|}
\hline $\begin{array}{c}\text { Sampl } \\
\text { e }\end{array}$ & $\begin{array}{c}\text { MD1 } \\
\text { b }\end{array}$ & $\begin{array}{c}\text { MM184 } \\
\text { b }\end{array}$ & $\begin{array}{c}\text { MM15 } \\
1\end{array}$ & $\begin{array}{c}\text { MM13 } \\
1\end{array}$ & $\begin{array}{c}\text { MM188 } \\
\text { C }\end{array}$ & $\begin{array}{c}\text { MM171 } \\
\text { c }\end{array}$ & $\begin{array}{c}\text { MM16 } \\
9\end{array}$ & $\begin{array}{c}\text { MM166a } \\
\text { c }\end{array}$ & $\begin{array}{c}\text { MM14 } \\
3\end{array}$ & $\begin{array}{c}\text { MM166 } \\
\text { C }\end{array}$ & $\begin{array}{c}\text { MM198c } \\
\text { c }\end{array}$ & $\begin{array}{c}\text { MM197 } \\
\text { A }\end{array}$ & $\begin{array}{c}\text { MD9a } \\
\text { c }\end{array}$ \\
\hline Zone & III & IV & $\mathbf{V}$ & $\mathbf{V}$ & Vm & Vm & Vm & VI & VI & VI & VI & VI & VIx \\
\hline $\mathrm{SiO}_{2}$ & 48.38 & 47.32 & 48.33 & 47.93 & 48.30 & 48.15 & 47.71 & 48.15 & 48.52 & 47.92 & 48.55 & 48.53 & 48.30 \\
\hline $\mathrm{Al}_{2} \mathrm{O}_{3}$ & 32.46 & 32.80 & 32.45 & 32.44 & 32.83 & 32.55 & 32.51 & 32.73 & 32.59 & 32.60 & 33.14 & 32.75 & 32.51 \\
\hline $\mathrm{MgO}$ & 6.76 & 6.75 & 7.02 & 6.75 & 7.80 & 6.79 & 6.26 & 6.32 & 7.54 & 6.84 & 8.48 & 7.59 & 5.93 \\
\hline $\mathrm{MnO}$ & 0.24 & 0.17 & 0.34 & 0.09 & 0.08 & 0.42 & 0.02 & 0.29 & 0.19 & 0.14 & 0.20 & 0.67 & 0.07 \\
\hline $\mathrm{FeO}^{\mathrm{a}}$ & 10.42 & 10.51 & 10.34 & 11.16 & 9.23 & 11.11 & 11.75 & 11.76 & 10.23 & 11.60 & 8.80 & 10.37 & 11.77 \\
\hline $\mathrm{Na}_{2} \mathrm{O}$ & 0.36 & 0.47 & 0.46 & 0.43 & 0.42 & 0.22 & 0.38 & 0.16 & 0.29 & 0.29 & 0.13 & 0.34 & 0.23 \\
\hline $\mathrm{K}_{2} \mathrm{O}$ & 0.00 & 0.07 & 0.04 & 0.08 & 0.08 & 0.00 & 0.00 & 0.00 & 0.00 & 0.03 & 0.00 & 0.00 & 0.00 \\
\hline Total & 98.62 & 98.09 & 98.98 & 98.88 & 98.74 & 99.24 & 98.63 & 99.41 & 99.36 & 99.42 & 99.28 & 100.25 & 98.81 \\
\hline $\mathrm{Si}$ & 5.02 & 4.95 & 5.00 & 4.98 & 4.98 & 4.99 & 4.98 & 4.99 & 4.99 & 4.96 & 4.97 & 4.97 & 5.03 \\
\hline $\mathrm{Al}$ & 3.97 & 4.04 & 3.96 & 3.97 & 3.99 & 3.97 & 4.00 & 4.00 & 3.95 & 3.98 & 4.00 & 3.95 & 3.99 \\
\hline $\mathrm{Mg}$ & 1.05 & 1.05 & 1.08 & 1.05 & 1.20 & 1.05 & 0.97 & 0.98 & 1.16 & 1.06 & 1.29 & 1.16 & 0.92 \\
\hline $\mathrm{Mn}$ & 0.02 & 0.02 & 0.03 & 0.01 & 0.01 & 0.04 & 0.00 & 0.03 & 0.02 & 0.01 & 0.02 & 0.06 & 0.01 \\
\hline $\mathrm{Fe}$ & 0.91 & 0.92 & 0.90 & 0.97 & 0.80 & 0.96 & 1.03 & 1.02 & 0.88 & 1.00 & 0.75 & 0.89 & 1.02 \\
\hline
\end{tabular}




\begin{tabular}{|c|c|c|c|c|c|c|c|c|c|c|c|c|c|}
\hline $\begin{array}{c}\text { Sampl } \\
\text { e }\end{array}$ & $\begin{array}{c}\text { MD1 } \\
\text { b }\end{array}$ & $\begin{array}{c}\text { MM184 } \\
\text { b }\end{array}$ & $\begin{array}{c}\text { MM15 } \\
1\end{array}$ & $\begin{array}{c}\text { MM13 } \\
1\end{array}$ & $\begin{array}{c}\text { MM188 } \\
\text { C }\end{array}$ & $\begin{array}{c}\text { MM171 } \\
\text { c }\end{array}$ & $\begin{array}{c}\text { MM16 } \\
9\end{array}$ & $\begin{array}{c}\text { MM166a } \\
\text { c }\end{array}$ & $\begin{array}{c}\text { MM14 } \\
3\end{array}$ & $\begin{array}{c}\text { MM166 } \\
\text { c }\end{array}$ & $\begin{array}{c}\text { MM198c } \\
\text { c }\end{array}$ & $\begin{array}{c}\text { MM197 } \\
\text { A }\end{array}$ & $\begin{array}{c}\text { MD9a } \\
\text { c }\end{array}$ \\
\hline Zone & III & IV & $\mathbf{V}$ & $\mathbf{V}$ & $\mathbf{V m}$ & $\mathbf{V m}$ & Vm & VI & VI & VI & VI & VI & VIx \\
\hline $\mathrm{Na}$ & 0.04 & 0.09 & 0.09 & 0.08 & 0.08 & 0.02 & 0.08 & 0.02 & 0.06 & 0.06 & 0.01 & 0.07 & 0.02 \\
\hline $\mathrm{K}$ & 0.00 & 0.01 & 0.01 & 0.01 & 0.01 & 0.00 & 0.00 & 0.00 & 0.01 & 0.00 & 0.00 & 0.00 & 0.00 \\
\hline Total & 11.01 & 11.08 & 11.07 & 11.08 & 11.07 & 11.03 & 11.06 & 11.02 & 11.06 & 11.08 & 11.04 & 11.09 & 10.99 \\
\hline \multicolumn{14}{|c|}{${ }^{\mathrm{a}} \mathrm{Fe}$ total as $\mathrm{Fe}^{2+}$} \\
\hline \multicolumn{14}{|c|}{${ }^{\mathrm{b}}$ Analysis from Droop \& Treloar (1981). } \\
\hline \multicolumn{14}{|c|}{${ }^{\mathrm{c}}$ Analyses from Moazzen et al. (2001). } \\
\hline \multicolumn{14}{|c|}{ m, melt present; $x$, xenolith. } \\
\hline
\end{tabular}


Table 2. FTIR mean wt $\%$ total $\mathrm{H}_{2} \mathrm{O}$, type $\mathrm{I}_{2} \mathrm{O}$, type $\mathrm{II}_{2} \mathrm{O}$ and $\mathrm{CO}_{2}$ for various cordierite samples across the Etive aureole.

\begin{tabular}{|c|c|c|c|c|c|c|c|c|c|c|}
\hline Sample & $\begin{array}{c}\text { Temperature } \\
\left({ }^{\circ} \mathrm{C}\right)\end{array}$ & $\begin{array}{c}\text { Number of } \\
\text { analyses }\end{array}$ & $\begin{array}{l}\mathrm{H}_{2} \mathrm{O} \text { I } \\
(\mathrm{wt} \%)\end{array}$ & $\begin{array}{l}\mathrm{H}_{2} \mathrm{O} \text { II } \\
(\mathrm{wt} \%)\end{array}$ & $\begin{array}{l}\text { Total } \\
\text { (wt\%) }\end{array}$ & $\begin{array}{c}\mathrm{CO}_{2} \\
(\mathrm{wt} \%)\end{array}$ & $\begin{array}{c}\mathrm{H}_{2} \mathrm{O} \mathbf{I} \\
(1 \sigma)\end{array}$ & $\begin{array}{c}\mathrm{H}_{2} \mathrm{O} \text { II } \\
(1 \sigma)\end{array}$ & $\begin{array}{c}\text { Total } \\
(1 \sigma)\end{array}$ & $\begin{array}{l}\mathrm{CO}_{2} \\
(1 \sigma)\end{array}$ \\
\hline MM181 & 610 & 10 & 0.769 & 0.664 & 1.433 & 0.101 & 0.035 & 0.073 & 0.068 & 0.007 \\
\hline MD1 & 620 & 8 & 0.708 & 0.755 & 1.462 & 0.078 & 0.048 & 0.051 & 0.084 & 0.015 \\
\hline MM129 & 640 & 10 & 0.809 & 0.591 & 1.400 & 0.099 & 0.092 & 0.131 & 0.104 & 0.016 \\
\hline MM184 & 660 & 10 & 0.757 & 0.583 & 1.340 & 0.089 & 0.065 & 0.078 & 0.057 & 0.005 \\
\hline MM151 & 665 & 11 & 0.772 & 0.581 & 1.353 & 0.098 & 0.026 & 0.064 & 0.069 & 0.006 \\
\hline MM131 & 665 & 8 & 0.857 & 0.633 & 1.490 & 0.077 & 0.083 & 0.085 & 0.153 & 0.005 \\
\hline MM185 & 670 & 7 & 0.722 & 0.639 & 1.362 & 0.090 & 0.060 & 0.037 & 0.079 & 0.006 \\
\hline MM176 & 670 & 8 & 0.809 & 0.606 & 1.415 & 0.103 & 0.050 & 0.036 & 0.065 & 0.010 \\
\hline MM133 & 680 & 14 & 0.843 & 0.558 & 1.402 & 0.089 & 0.039 & 0.026 & 0.065 & 0.018 \\
\hline MM186 & 680 & 19 & 0.734 & 0.633 & 1.368 & 0.110 & 0.068 & 0.066 & 0.074 & 0.047 \\
\hline MM187 & 680 & 14 & 0.706 & 0.677 & 1.383 & 0.117 & 0.052 & 0.057 & 0.088 & 0.075 \\
\hline MM135 & 685 & 11 & 0.789 & 0.441 & 1.230 & 0.115 & 0.064 & 0.059 & 0.093 & 0.031 \\
\hline MM188 & 685 & 11 & 0.722 & 0.466 & 1.188 & 0.080 & 0.062 & 0.059 & 0.094 & 0.022 \\
\hline MM174 & 685 & 12 & 0.722 & 0.432 & 1.154 & 0.120 & 0.057 & 0.047 & 0.053 & 0.034 \\
\hline
\end{tabular}




\begin{tabular}{|c|c|c|c|c|c|c|c|c|c|c|}
\hline Sample & $\begin{array}{c}\text { Temperature } \\
\left({ }^{\circ} \mathrm{C}\right)\end{array}$ & $\begin{array}{c}\text { Number of } \\
\text { analyses }\end{array}$ & $\begin{array}{l}\mathrm{H}_{2} \mathrm{O} \mathrm{I} \\
(\mathrm{wt} \%)\end{array}$ & $\begin{array}{l}\mathrm{H}_{2} \mathrm{O} \text { II } \\
(\mathrm{wt} \%)\end{array}$ & $\begin{array}{l}\text { Total } \\
(\mathrm{wt} \%)\end{array}$ & $\begin{array}{c}\mathrm{CO}_{2} \\
(\mathrm{wt} \%)\end{array}$ & $\begin{array}{c}\mathrm{H}_{2} \mathrm{O} \mathrm{I} \\
(1 \sigma)\end{array}$ & $\begin{array}{c}\mathrm{H}_{2} \mathrm{O} \text { II } \\
(1 \sigma)\end{array}$ & $\begin{array}{l}\text { Total } \\
(1 \sigma)\end{array}$ & $\begin{array}{l}\mathrm{CO}_{2} \\
(1 \sigma)\end{array}$ \\
\hline MD12 & 690 & 8 & 0.683 & 0.521 & 1.204 & 0.114 & 0.061 & 0.092 & 0.088 & 0.044 \\
\hline MM171 & 700 & 45 & 0.687 & 0.473 & 1.160 & 0.072 & 0.054 & 0.064 & 0.072 & 0.031 \\
\hline MM144 & 705 & 11 & 0.697 & 0.343 & 1.040 & 0.113 & 0.035 & 0.048 & 0.051 & 0.033 \\
\hline MM195A & 710 & 12 & 0.722 & 0.370 & 1.092 & 0.104 & 0.051 & 0.035 & 0.067 & 0.022 \\
\hline MM169 & 715 & 11 & 0.647 & 0.373 & 1.020 & 0.117 & 0.034 & 0.049 & 0.073 & 0.036 \\
\hline MM166A & 730 & 9 & 0.577 & 0.268 & 0.845 & 0.092 & 0.088 & 0.032 & 0.104 & 0.016 \\
\hline MM164 & 730 & 12 & 0.653 & 0.404 & 1.056 & 0.107 & 0.035 & 0.098 & 0.131 & 0.030 \\
\hline MM143 & 735 & 12 & 0.630 & 0.276 & 0.906 & 0.111 & 0.054 & 0.054 & 0.093 & 0.028 \\
\hline MM194B & 740 & 16 & 0.675 & 0.343 & 1.018 & 0.107 & 0.038 & 0.069 & 0.072 & 0.027 \\
\hline MM166E & 745 & 28 & 0.552 & 0.324 & 0.876 & 0.095 & 0.032 & 0.079 & 0.095 & 0.027 \\
\hline MM166F & 745 & 11 & 0.577 & 0.354 & 0.931 & 0.113 & 0.054 & 0.065 & 0.065 & 0.020 \\
\hline MM166C & 745 & 8 & 0.570 & 0.266 & 0.836 & 0.090 & 0.094 & 0.031 & 0.111 & 0.019 \\
\hline MM166D & 745 & 11 & 0.599 & 0.275 & 0.874 & 0.100 & 0.030 & 0.030 & 0.054 & 0.017 \\
\hline MD19 & 750 & 12 & 0.584 & 0.272 & 0.856 & 0.091 & 0.033 & 0.060 & 0.090 & 0.012 \\
\hline MD18 & 765 & 12 & 0.699 & 0.389 & 1.088 & 0.118 & 0.049 & 0.060 & 0.094 & 0.036 \\
\hline
\end{tabular}




\begin{tabular}{|c|c|c|c|c|c|c|c|c|c|c|}
\hline Sample & $\begin{array}{c}\text { Temperature } \\
\left({ }^{\circ} \mathrm{C}\right)\end{array}$ & $\begin{array}{c}\text { Number of } \\
\text { analyses }\end{array}$ & $\begin{array}{l}\mathrm{H}_{2} \mathrm{O} \text { I } \\
(\mathrm{wt} \%)\end{array}$ & $\begin{array}{l}\mathrm{H}_{2} \mathrm{O} \text { II } \\
(\mathrm{wt} \%)\end{array}$ & $\begin{array}{l}\text { Total } \\
(\mathrm{wt} \%)\end{array}$ & $\begin{array}{c}\mathrm{CO}_{2} \\
(\mathrm{wt} \%)\end{array}$ & $\begin{array}{c}\mathrm{H}_{2} \mathrm{O} \text { I } \\
(1 \sigma)\end{array}$ & $\begin{array}{c}\mathrm{H}_{2} \mathrm{O} \text { II } \\
(1 \sigma)\end{array}$ & $\begin{array}{l}\text { Total } \\
(1 \sigma)\end{array}$ & $\begin{array}{l}\mathrm{CO}_{2} \\
(1 \sigma)\end{array}$ \\
\hline MM198c & 780 & 10 & 0.655 & 0.316 & 0.971 & 0.088 & 0.039 & 0.036 & 0.063 & 0.013 \\
\hline MM197A & 780 & 14 & 0.684 & 0.300 & 0.984 & 0.103 & 0.060 & 0.046 & 0.089 & 0.026 \\
\hline MM193Y & 800 & 12 & 0.670 & 0.520 & 1.190 & 0.233 & 0.079 & 0.057 & 0.100 & 0.057 \\
\hline MD9A & 1000 & 15 & 0.753 & 0.511 & 1.263 & 0.249 & 0.061 & 0.079 & 0.110 & 0.081 \\
\hline MD9B & 1000 & 10 & 0.594 & 0.420 & 1.014 & 0.188 & 0.065 & 0.094 & 0.117 & 0.078 \\
\hline
\end{tabular}

Table 3. Calculated mean values of $n, m, a \mathrm{H}_{2} \mathrm{O}$ and $a \mathrm{CO}_{2}$.

\begin{tabular}{|c|c|c|c|c|c|c|c|c|c|c|c|c|c|}
\hline Sample & $\mathrm{T}\left({ }^{\circ} \mathrm{C}\right)$ & $n\left(\mathbf{H}_{2} \mathbf{O}\right)$ & $1 \sigma$ & $m\left(\mathrm{CO}_{2}\right)$ & $1 \sigma$ & $\mathrm{XCO}_{2}$ & $m+n$ & $a \mathbf{H}_{2} \mathbf{O}$ & $1 \sigma$ & Error $^{a}$ & $a \mathrm{CO}_{2}$ & $1 \sigma$ & Error $^{\mathrm{a}}$ \\
\hline MM181 & 610 & 0.495 & 0.032 & 0.014 & 0.001 & 0.028 & 0.509 & 0.902 & 0.266 & 0.083 & 0.101 & 0.078 & 0.011 \\
\hline MD1 & 620 & 0.504 & 0.036 & 0.011 & 0.002 & 0.021 & 0.515 & 0.956 & 0.287 & 0.098 & 0.080 & 0.064 & 0.021 \\
\hline MM129 & 640 & 0.483 & 0.042 & 0.014 & 0.002 & 0.028 & 0.496 & 0.920 & 0.289 & 0.114 & 0.108 & 0.086 & 0.025 \\
\hline MM184B & 660 & 0.463 & 0.030 & 0.013 & 0.001 & 0.026 & 0.476 & 0.892 & 0.275 & 0.081 & 0.104 & 0.079 & 0.009 \\
\hline MM151 & 665 & 0.478 & 0.033 & 0.014 & 0.001 & 0.028 & 0.492 & 0.959 & 0.299 & 0.092 & 0.115 & 0.088 & 0.010 \\
\hline MM131 & 665 & 0.517 & 0.057 & 0.011 & 0.001 & 0.021 & 0.528 & 1.119 & 0.375 & 0.175 & 0.091 & 0.070 & 0.008 \\
\hline
\end{tabular}




\begin{tabular}{|c|c|c|c|c|c|c|c|c|c|c|c|c|c|}
\hline Sample & $\mathrm{T}\left({ }^{\circ} \mathrm{C}\right)$ & $n\left(\mathrm{H}_{2} \mathrm{O}\right)$ & $1 \sigma$ & $m\left(\mathrm{CO}_{2}\right)$ & $1 \sigma$ & $\mathrm{XCO}_{2}$ & $m+n$ & $a \mathrm{H}_{2} \mathrm{O}$ & $1 \sigma$ & Error $^{a}$ & $a \mathrm{CO}_{2}$ & $1 \sigma$ & Error $^{\mathrm{a}}$ \\
\hline MM185B & 670 & 0.466 & 0.035 & 0.013 & 0.001 & 0.026 & 0.478 & 0.922 & 0.292 & 0.097 & 0.107 & 0.082 & 0.011 \\
\hline MM176 & 670 & 0.489 & 0.031 & 0.015 & 0.001 & 0.029 & 0.504 & 1.012 & 0.316 & 0.092 & 0.123 & 0.095 & 0.017 \\
\hline MM133 & 680 & 0.484 & 0.031 & 0.013 & 0.003 & 0.025 & 0.497 & 1.029 & 0.325 & 0.094 & 0.109 & 0.089 & 0.031 \\
\hline MM186B & 680 & 0.473 & 0.034 & 0.016 & 0.007 & 0.032 & 0.489 & 0.985 & 0.313 & 0.099 & 0.136 & 0.132 & 0.082 \\
\hline MM187 & 680 & 0.483 & 0.038 & 0.017 & 0.011 & 0.034 & 0.500 & 1.012 & 0.325 & 0.112 & 0.147 & 0.173 & 0.133 \\
\hline MM135A & 685 & 0.425 & 0.039 & 0.016 & 0.004 & 0.037 & 0.441 & 0.810 & 0.267 & 0.105 & 0.144 & 0.123 & 0.055 \\
\hline MM188C & 685 & 0.409 & 0.039 & 0.011 & 0.003 & 0.027 & 0.420 & 0.758 & 0.252 & 0.103 & 0.100 & 0.085 & 0.038 \\
\hline MM174B & 685 & 0.397 & 0.029 & 0.017 & 0.005 & 0.041 & 0.414 & 0.722 & 0.231 & 0.074 & 0.150 & 0.129 & 0.061 \\
\hline MD12 & 690 & 0.414 & 0.037 & 0.016 & 0.006 & 0.037 & 0.430 & 0.784 & 0.260 & 0.100 & 0.144 & 0.135 & 0.078 \\
\hline MM171 & 700 & 0.405 & 0.033 & 0.010 & 0.004 & 0.025 & 0.415 & 0.772 & 0.255 & 0.090 & 0.095 & 0.092 & 0.057 \\
\hline MM144 & 705 & 0.359 & 0.028 & 0.016 & 0.005 & 0.043 & 0.375 & 0.643 & 0.213 & 0.071 & 0.150 & 0.130 & 0.062 \\
\hline MM195A & 710 & 0.377 & 0.032 & 0.015 & 0.003 & 0.037 & 0.392 & 0.704 & 0.236 & 0.084 & 0.139 & 0.114 & 0.041 \\
\hline MM169 & 715 & 0.355 & 0.034 & 0.017 & 0.005 & 0.045 & 0.372 & 0.648 & 0.222 & 0.087 & 0.160 & 0.141 & 0.071 \\
\hline MM166A & 730 & 0.292 & 0.042 & 0.013 & 0.002 & 0.042 & 0.305 & 0.503 & 0.192 & 0.103 & 0.129 & 0.104 & 0.032 \\
\hline MM164 & 730 & 0.365 & 0.050 & 0.015 & 0.004 & 0.040 & 0.380 & 0.699 & 0.263 & 0.136 & 0.152 & 0.130 & 0.060 \\
\hline MM143 & 735 & 0.311 & 0.039 & 0.016 & 0.004 & 0.048 & 0.327 & 0.556 & 0.205 & 0.098 & 0.158 & 0.133 & 0.056 \\
\hline
\end{tabular}




\begin{tabular}{|c|c|c|c|c|c|c|c|c|c|c|c|c|c|}
\hline Sample & $\mathrm{T}\left({ }^{\circ} \mathrm{C}\right)$ & $n\left(\mathbf{H}_{2} \mathbf{O}\right)$ & $1 \sigma$ & $m\left(\mathrm{CO}_{2}\right)$ & $1 \sigma$ & $X \mathrm{CO}_{2}$ & $m+n$ & $a \mathbf{H}_{2} \mathrm{O}$ & $1 \sigma$ & Error $^{a}$ & $a \mathrm{CO}_{2}$ & $1 \sigma$ & Error $^{\mathrm{a}}$ \\
\hline MM194B & 740 & 0.352 & 0.033 & 0.015 & 0.004 & 0.041 & 0.367 & 0.676 & 0.239 & 0.090 & 0.155 & 0.131 & 0.056 \\
\hline MM166E & 745 & 0.303 & 0.039 & 0.013 & 0.004 & 0.042 & 0.316 & 0.548 & 0.207 & 0.101 & 0.139 & 0.120 & 0.056 \\
\hline MM166F & 745 & 0.322 & 0.031 & 0.016 & 0.003 & 0.047 & 0.338 & 0.598 & 0.214 & 0.083 & 0.166 & 0.133 & 0.042 \\
\hline MM166C & 745 & 0.289 & 0.044 & 0.013 & 0.003 & 0.042 & 0.302 & 0.512 & 0.202 & 0.111 & 0.133 & 0.109 & 0.039 \\
\hline MM166D & 745 & 0.304 & 0.029 & 0.014 & 0.002 & 0.045 & 0.318 & 0.549 & 0.196 & 0.074 & 0.148 & 0.118 & 0.035 \\
\hline MD19 & 750 & 0.296 & 0.038 & 0.013 & 0.002 & 0.042 & 0.309 & 0.537 & 0.203 & 0.098 & 0.135 & 0.107 & 0.025 \\
\hline MD18 & 765 & 0.377 & 0.039 & 0.017 & 0.005 & 0.043 & 0.393 & 0.797 & 0.295 & 0.117 & 0.183 & 0.161 & 0.079 \\
\hline MM198c & 780 & 0.332 & 0.031 & 0.012 & 0.002 & 0.036 & 0.344 & 0.680 & 0.252 & 0.089 & 0.139 & 0.111 & 0.030 \\
\hline MM197A & 780 & 0.336 & 0.038 & 0.014 & 0.004 & 0.041 & 0.351 & 0.693 & 0.264 & 0.110 & 0.163 & 0.137 & 0.057 \\
\hline MM193Y & 800 & 0.412 & 0.041 & 0.033 & 0.008 & 0.074 & 0.445 & 1.005 & 0.386 & 0.142 & 0.400 & 0.336 & 0.138 \\
\hline MD9A & 1000 & 0.437 & 0.044 & 0.035 & 0.011 & 0.075 & 0.472 & 1.783 & 0.899 & 0.253 & 0.641 & 0.577 & 0.294 \\
\hline MD9B & 1000 & 0.351 & 0.046 & 0.027 & 0.011 & 0.071 & 0.377 & 1.242 & 0.644 & 0.231 & 0.480 & 0.465 & 0.280 \\
\hline \multicolumn{14}{|c|}{$1 \sigma$ error is the total error. } \\
\hline
\end{tabular}


Table 4. Calculated mean values of melt wt $\% \mathrm{H}_{2} \mathrm{O}$ and $D_{w}$.

\begin{tabular}{|c|c|c|c|c|c|c|}
\hline Sample & $\begin{array}{c}T \\
\left({ }^{\circ} \mathrm{C}\right)\end{array}$ & $\begin{array}{c}\text { Cordierite } \mathrm{H}_{2} \mathrm{O} \text { content } \\
\text { (wt } \%)\end{array}$ & $\begin{array}{c}\text { Error }^{\mathrm{a}} \text { in cordierite } \mathrm{H}_{2} \mathrm{O} \\
\text { content }\end{array}$ & $\begin{array}{c}\text { Melt } \mathrm{H}_{2} \mathrm{O} \text { content } \\
(\mathrm{wt} \%)\end{array}$ & $\begin{array}{c}\text { Error }{ }^{\mathrm{b}} \text { in melt } \mathrm{H}_{2} \mathrm{O} \\
(\mathrm{wt} \%)\end{array}$ & $D_{w}$ \\
\hline MM133 & 680 & 1.402 & 0.065 & 6.17 & 2.49 & 4.40 \\
\hline MM186B & 680 & 1.368 & 0.074 & 5.93 & 2.18 & 4.33 \\
\hline MM187 & 680 & 1.401 & 0.088 & 6.08 & 2.43 & 4.34 \\
\hline MM135A & 685 & 1.230 & 0.093 & 5.09 & 1.32 & 4.14 \\
\hline MM188C & 685 & 1.188 & 0.094 & 4.81 & 1.08 & 4.05 \\
\hline MM174B & 685 & 1.154 & 0.053 & 4.61 & 0.90 & 4.00 \\
\hline MD12 & 690 & 1.203 & 0.088 & 4.92 & 1.14 & 4.09 \\
\hline MM171 & 700 & 1.160 & 0.072 & 4.83 & 1.07 & 4.17 \\
\hline MM144 & 705 & 1.040 & 0.067 & 4.15 & 0.61 & 3.99 \\
\hline MM195A & 710 & 1.092 & 0.073 & 4.47 & 0.83 & 4.10 \\
\hline MM169 & 715 & 1.020 & 0.051 & 4.19 & 0.69 & 4.10 \\
\hline MM166A & 730 & 0.845 & 0.131 & 3.44 & 0.36 & 4.08 \\
\hline MM164 & 730 & 1.056 & 0.093 & 4.42 & 0.92 & 4.19 \\
\hline MM143 & 735 & 0.906 & 0.072 & 3.69 & 0.47 & 4.08 \\
\hline
\end{tabular}




\begin{tabular}{|c|c|c|c|c|c|c|}
\hline Sample & $\begin{array}{c}T \\
\left({ }^{\circ} \mathrm{C}\right)\end{array}$ & $\begin{array}{c}\text { Cordierite } \mathrm{H}_{2} \mathrm{O} \text { content } \\
\text { (wt } \%)\end{array}$ & $\begin{array}{c}\text { Error }{ }^{\mathrm{a}} \text { in cordierite } \mathrm{H}_{2} \mathrm{O} \\
\text { content }\end{array}$ & $\begin{array}{c}\text { Melt } \mathrm{H}_{2} \mathrm{O} \text { content } \\
(\mathrm{wt} \%)\end{array}$ & $\begin{array}{c}\text { Error }^{\mathrm{b}} \text { in melt } \mathrm{H}_{2} \mathrm{O} \\
(\mathrm{wt} \%)\end{array}$ & $D_{w}$ \\
\hline MM194B & 740 & 1.018 & 0.104 & 4.30 & 0.79 & 4.22 \\
\hline MM166E & 745 & 0.876 & 0.095 & 3.65 & 0.46 & 4.16 \\
\hline MM166F & 745 & 0.933 & 0.065 & 3.90 & 0.56 & 4.18 \\
\hline MM166C & 745 & 0.836 & 0.111 & 3.47 & 0.40 & 4.15 \\
\hline MM166D & 745 & 0.874 & 0.054 & 3.63 & 0.43 & 4.15 \\
\hline MD19 & 750 & 0.856 & 0.090 & 3.58 & 0.44 & 4.18 \\
\hline MD18 & 765 & 1.088 & 0.094 & 4.85 & 1.30 & 4.46 \\
\hline MM198c & 780 & 0.971 & 0.063 & 4.27 & 0.82 & 4.39 \\
\hline MM197A & 780 & 0.984 & 0.089 & 4.32 & 0.88 & 4.39 \\
\hline MM193Y & 800 & 1.190 & 0.100 & 5.85 & 2.64 & 4.91 \\
\hline MD9A & 1000 & 1.263 & 0.110 & 10.51 & 12.61 & 8.32 \\
\hline MD9B & 1000 & 1.014 & 0.117 & 7.09 & 4.46 & 6.99 \\
\hline \multicolumn{7}{|c|}{${ }^{a}$ Error reports the uncertainty in the analytical population and the FTIR calibration. } \\
\hline
\end{tabular}

